\title{
The Palaeolithic record of Warsash, Hampshire, UK: implications for late Lower and early Middle Palaeolithic occupation history of Southern Britain
}

Article

Accepted Version

Creative Commons: Attribution-Noncommercial-No Derivative Works 4.0

Davis, R. J., Hatch, M., Ashton, N., Hosfield, R. and Lewis, S. G. (2016) The Palaeolithic record of Warsash, Hampshire, UK: implications for late Lower and early Middle Palaeolithic occupation history of Southern Britain. Proceedings of the Geologists' Association, 127 (5). pp. 558-574. ISSN 00167878 doi: https://doi.org/10.1016/j.pgeola.2016.09.005 Available at https://centaur.reading.ac.uk/68003/

It is advisable to refer to the publisher's version if you intend to cite from the work. See Guidance on citing.

To link to this article DOI: http://dx.doi.org/10.1016/j.pgeola.2016.09.005

Publisher: Elsevier

All outputs in CentAUR are protected by Intellectual Property Rights law, including copyright law. Copyright and IPR is retained by the creators or other copyright holders. Terms and conditions for use of this material are defined in the End User Agreement. 


\section{www.reading.ac.uk/centaur}

\section{CentAUR}

Central Archive at the University of Reading

Reading's research outputs online 


\section{Author's Original Manuscript - Postprint}

This is an Author's Accepted Manuscript of an article published as: Davis, R.J., Hatch, M., Ashton, N., Hosfield, R. \& Lewis, S.G. In press. The Palaeolithic record of Warsash, Hampshire, UK: implications for late Lower and early Middle Palaeolithic occupation history of Southern Britain. Proceedings of the Geologists' Association. 
The Palaeolithic record of Warsash, Hampshire, UK: implications for late Lower and Early Middle Palaeolithic occupation history of Southern Britain.

\author{
Robert J. Davis ${ }^{a, *}$, Marcus Hatch ${ }^{b}$, Nick Ashtonc, Rob Hosfield ${ }^{a}$, Simon G. Lewis ${ }^{b}$ \\ a Department of Archaeology, University of Reading, Reading RG6 6AH, UK \\ b School of Geography, Queen Mary University of London, London E1 4NS, UK \\ c Department of Britain, Europe and Prehistory, British Museum, 56 Orsman Road, London N1 \\ $5 Q J, U K$ \\ * Corresponding author. \\ E-mail address: r.davis@qmul.ac.uk \\ Postal address: School of Geography, Queen Mary University of London, Mile End Road, \\ London, E1 4NS, UK
}

\title{
ABSTRACT
}

This paper presents new work on the Lower and Middle Palaeolithic assemblages recovered from Pleistocene gravels of the River Test at Warsash, Hampshire. Historic map and artefact analyses enable the geological context to be established for substantial portions of the Warsash Palaeolithic record, which, when combined with new data relating to regional terrace stratigraphy and chronology, enables Warsash to be incorporated within regional and national Palaeolithic frameworks. Three key assemblages are identified: 1) a handaxe-dominated assemblage associated with gravels of the Lower Warsash Terrace that is likely to relate to hominin occupation during MIS 9;2) a Levallois assemblage probably related to sediments overlying the Lower Warsash Terrace and likely to represent occupation in late MIS 8 and/or MIS 7 ; 3 ) a handaxe-dominated assemblage recovered from gravels of the Hamble Terrace, which is likely to have been reworked from older terrace fragments. The presence at Warsash of ficrons, cleavers and plano-convex handaxes is confirmed and their potential chronological significance considered. The Levallois record of the Solent Basin is discussed, highlighting its impoverished nature relative to the rich Levallois record of the Thames Valley. It is argued that preservation bias and/or collection history have not played a major role in creating these differences. Instead, it is likely to represent the limited dispersal of Neanderthal populations further into Britain from an entry point in the southern North Sea Basin.

Keywords: Middle Pleistocene, Palaeolithic, Handaxes, Levallois, Solent, Warsash

\section{Introduction}

A number of recent studies have provided evidence of a greater complexity to the Middle Pleistocene human occupation of Britain than had previously been recognised. These include evidence for chronological patterning in Lower Palaeolithic handaxe typology (Wenban-Smith 2004; Pettitt and White 2012; Davis 2013; Bridgland and White 2014; White 2015) and regional variation in Early Middle Palaeolithic occupation and technology (Ashton and Hosfield 2010; Ashton et al. 2011, 2015; Bates et al. 2014). The changing palaeogeography of Britain is likely to have played a role in forming some of this patterning, from which there are also important wider implications for our understanding of human dispersals in northwest Europe during the late Middle Pleistocene (Ashton and Hosfield 2010; Bridgland and White 2014; Davis 2013; Ashton et al. 2015).

The Solent Basin (Fig. 1) has a vital role to play in revealing the full complexity of human occupation in Britain during the Lower and Middle Palaeolithic. The Pleistocene fluvial sands and gravels of the River Solent and its major tributaries - the rivers Frome, Stour, Avon, Test and Itchen - have long been recognised as a rich source of Palaeolithic artefacts (Evans 1897; Bury 1923, 1933; Wessex Archaeology 1993). In particular, Lower Palaeolithic handaxes are abundant, and it has been suggested that the Solent Basin was one of the most favoured places 
for human occupation in Britain during the Lower Palaeolithic (Wymer 1999). Importantly, its long terrace sequences provide an archaeological record of human presence in southern Britain to compare to the Thames and East Anglian records of eastern Britain. One important contrast between these regions is the relative dearth of Levallois artefacts in the Solent (Ashton and Hosfield 2010; Ashton et al. 2015), which has been interpreted as evidence of regional variation in the nature of Early Middle Palaeolithic occupation in Britain (Ashton and Hosfield 2010; Ashton et al. 2011; Pettitt and White 2012; Bates et al. 2014).

Central to discussions of the late Lower Palaeolithic and Early Middle Palaeolithic record of the Solent is Warsash, a village in southern Hampshire situated on the eastern flank of Southampton Water, $5 \mathrm{~km}$ south-east of Southampton (Fig. 1). Here, extensive quarrying of gravels associated with the Hamble Terrace and Lower Warsash Terrace of the River Test (Westaway et al. 2006; Harding et al. 2012), mapped as Terrace 2 and Terrace 3 respectively by the British Geological Survey (BGS; Edwards and Freshney 1987), has produced a rich Palaeolithic record that includes at least 499 handaxes and 34 Levallois artefacts. While this Levallois assemblage is small by most standards, it is more than double the size of the next largest in the Solent Basin (Wessex Archaeology 1993), and its relationship to the large number of handaxes recovered from the same gravel pits is key to understanding the nature of Early Middle Palaeolithic occupation in the region and in Britain more widely. The handaxes are of interest too, both for their association with terrace gravels that appear to date to a period of time usually associated with Middle Palaeolithic technology, and for the presence of a number of handaxe types that are argued to have chronological significance (Roe 1981, 2001; Bridgland and White 2014; White 2015).

Unfortunately, the Warsash Palaeolithic record suffers from an absence of detailed contextual information, which has made it difficult to be certain which artefacts came from which terrace, and has obscured the relationship between the Lower and Middle Palaeolithic material. This absence of contextual information combined with some uncertainty over the mapping of the terrace gravels (Hatch 2014; Hatch et al. in revision.) has prevented the full interpretative potential of Warsash from being realised. This paper seeks to resolve some of the contextual uncertainties that surround the Warsash record, and to reveal its significance for current understanding of Lower and Middle Palaeolithic occupation in Southern England.

[Figure 1 - full width - colour online only]

\section{Previous work}

The Palaeolithic potential of the gravels in the Warsash area became apparent during the late $19^{\text {th }}$ Century when large numbers of handaxes were recovered from the shore of Southampton Water between Warsash and Brown Down, presumably eroded from the Hamble Terrace gravels exposed in the adjacent cliffs (Evans 1872, 1897). However, collecting from the Warsash gravels only began in earnest during the mid-1920s, when a number of large gravel pits were established. Major gravel extraction ceased in the area during the 1970s. Artefacts were recovered throughout this time by numerous collectors (Table 1).

The largest collection of Warsash palaeoliths was assembled by Mr C. J. Mogridge of Winchester Museum. He was active in the area between the 1920s and 1950s, although the majority of his collection appears to have been formed by 1940 . As is the case for many of the collectors who operated at Warsash, Mogridge typically only recorded an artefact as coming from Warsash, and rarely recorded a more specific geological or geographical provenance. Accounting for approximately half of the total known Warsash record, the Mogridge Collection formed the basis of the only notable paper to date to have addressed the Warsash Palaeolithic record. Burkitt et al. (1939) provided the names of the four gravel pits - Dyke's Pit, New Pit, Park's Pit and Newbury's Pit - from which Mogridge amassed his collection, which they 
described as being located between Warsash and Hook. Unfortunately, Burkitt et al. did not provide specific locations for the pits. They also did not indicate the number or type of artefacts to have been recovered from each pit, and only provided limited information regarding the geological context of the artefacts. Given that multiple terraces of the River Test are present in the Warsash area, this presents a major difficulty for analysis of the Warsash record within the framework of terrace stratigraphy, and explains its exclusion from two recent studies of the area (Bates et al. 2004; Ashton and Hosfield 2010).

[Table 1 - full width]

Burkitt et al. (1939) split the Mogridge Collection into four chronological series: Early, Middle and Late (Micoquian) Acheulean, and Levalloisian. These divisions were based on typology, technology and the condition of the material and influenced by contemporary views of handaxe typology and linear technological progression. Their Early Acheulean series was formed of rolled, crude handaxes, while their Middle Acheulean series, which represented the majority of the assemblage, was formed of points, ovates (including what they term hand-choppers) and cleavers. Their Late Acheulean series, which they argued was fresher than the Middle Acheulean material and comparable to Continental Micoquian assemblages, was characterised by "shapely coup-de-poing, made on flakes and showing little or no working on the main flake surface." (Burkitt et al. 1939:40). The Levalloisian series consisted of cores and flakes produced through the Levallois technique and was in a fresher condition than the Acheulean series.

Burkitt et al. made two further interesting observations of the Warsash handaxes. The first is the occurrence of edge modifications in the form of notches to the lateral edges of some handaxes, including one example where variation in patination led them to suggest that the notches were made sometime after the handaxe was manufactured. Second is the presence of pointed, planoconvex handaxes, some of which are manufactured on flakes with minimal working to the ventral face (Shackley 1977; Roe 1981). It is a result of this second observation that Warsash has been repeatedly cited as a potential source of comparative handaxes to the famous plano-convex pointed handaxes from Wolvercote, Oxfordshire (Roe 1981; Tyldesley 1986; Ashton 2001; Wenban-Smith 2001). Variously ascribed to cultural (Roe 1981; Tyldesley 1986), raw material (White 1998) and resharpening (Ashton 2001) factors, the Wolvercote plano-convex handaxes are argued to date to the MIS 9 interglacial (Bridgland 1994; Bridgland and White 2015). Warsash has also been highlighted for the presence of ficrons and cleavers within its handaxe assemblage (Roe 2001), which, when occurring in combination and in significant numbers, are also argued to be characteristic of some handaxe assemblages manufactured between MIS 108 (Roe 2001; Wenban-Smith 2004; Pettitt and White 2012; Bridgland and White 2014).

[Figure 2 - full width - colour online only]

Burkitt et al. (1939) provided a description of the geology at Warsash based on a $3.5 \mathrm{~m}$ composite section of a number of pit faces revealed at Newbury's Pit (Fig. 2). At the base of the section they described Barton Sand (10) rising in hummocks over which lies a coarse brown gravel conglomerate (9). Above this lies $1.8 \mathrm{~m}$ to $2.4 \mathrm{~m}$ of coarse, loose, ferruginous gravel (8) overlain by a non-ferruginous, grey, clayey sand (7). On top of this lies a finer gravel (6), which is disconformably overlain by a fine, even-bedded, gravelly sand with occasional sand lenses (5). Above this is $0.3 \mathrm{~m}$ of fine angular gravel (4) covered by a buff, stony loam (3) and capped by a black pebbly sand (1), which has a thin basal layer of angular gravel (2). They stated that the lower gravels (8) were the source of both the Early and Middle Acheulean, but offer no suggestion of the source of the Later Acheulean handaxes. With regards to the context of the Levallois material, they reported that Levallois artefacts were recovered from beneath a blue clay at Park's Pit, which they suggest might be equivalent to the stony loam (3) that overlies the terrace deposits at Newbury's Pit. 
In the 1970s, Shackley $(1974,1978)$ conducted some small-scale archaeological fieldwork at Fleet End Pits, east of Warsash. These pits exploited sands and gravels of the Lower Warsash Terrace. She recovered a small lithic assemblage that included handaxes and one Levallois core from a concentration of relatively large cobbles within a layer of finer material, which she interpreted as a fossilised gravel bar (Shackley 1978). Employing a microscopic method to measure abrasion, Shackley identified variation in artefact condition, suggesting that the assemblage was a composite of gravels and artefacts of different ages reworked from a number of preserved terrace fragments upstream. Importantly, the variation in artefact condition appeared to follow technological distinctions, with rolled handaxes contrasting the fresh Levallois core. Ashton and Hosfield (2010) have observed this same general distinction in condition between handaxes and Levallois artefacts at Warsash and from the Solent region as a whole. They suggested that the freshness and patination typical of the Levallois artefacts in the region may be indicative of their origin within fine-grained deposits overlying the terrace gravels, an interpretation that may be supported by the above observations of Burkitt et al. (1939). Shackley's observations at the Fleet End Pits appear to contradict this, although it remains a possibility that the Levallois core was recovered from the surface of the gravel bar and not within it.

\section{The Warsash Terrace Mapping}

Warsash is underlain by the Tertiary bedrock of the Hampshire Basin. The superficial deposits are predominantly fluvial gravels laid down by the River Test (Fig. 3a), with some overlying brickearths to the southeast. The BGS mapping of the terraces of the River Test (Edwards and Freshney 1987; Booth 2002) has been modified by Westaway et al. (2006; Harding et al. 2012), who introduced a scheme with named terraces, Briant et al. (2012) and Hatch (2014; Hatch et al. in revision; see Table 2). The earlier schemes recognised two terraces in the areas affected by gravel extraction: Terrace 3 under and immediately south and east of Warsash, and Terrace 2 at a lower altitude to the south. These were named the Warsash Terrace and Hamble Terrace respectively by Westaway et al. (2006). A reanalysis of the local terrace mapping based on borehole records and GPR survey suggests some alterations need to be made to this earlier mapping (Hatch 2014; Hatch et al. in revision.; Fig. 3b). This is discussed in detail by Hatch et al. (in revision) and the key findings are summarised here.

[Figure 3 - full width - colour online only]

First, analysis of borehole data for the large spread of gravel that underlies Warsash and is mapped as Terrace 3 by the BGS reveals gravel body geometry that is clearly related to two terraces, Terrace 3 in the south and Terrace 4 in the north. These were named the Lower Warsash Terrace and Upper Warsash Terrace respectively by Harding et al. (2012). This has important implications for upstream correlations of Warsash with the archaeologically-rich gravels in the vicinity of Romsey and Dunbridge in the Test Valley. Westaway et al. (2006) used surface heights to correlate the spread of Terrace 3 gravels at Warsash with their Belbin Terrace (Terrace 4) in the Romsey region. However, their correlation was based on a surface height of $25 \mathrm{~m}$ OD in the Warsash area, which actually equates to the Upper Warsash Terrace (Terrace 4; Ashton and Hosfield 2010; Harding et al. 2012; Hatch 2014; Hatch et al. in revision.). Importantly, all of the gravel pits that produced archaeology in the vicinity of Warsash exploited either the Lower Warsash Terrace (Terrace 3) gravels, for which the Mottisfont Terrace (Terrace 3 ) is an upstream correlative, or the Hamble Terrace (Terrace 2) gravels to the south. So instead of placing the Romsey/Dunbridge and Warsash archaeology in equivalent terrace deposits, they are placed in the older Belbin Terrace and younger Lower Warsash and Hamble terraces respectively. Archaeology that is comparable to the Warsash material is therefore found at sites related to the Hamble, Lower Warsash and Mottisfont terraces, including Hill Head and Lee-onSolent (Hamble Terrace), and Kimbridge and Colden Common (Mottisfont Terrace; Fig. 1). 
[Table 2 - full width]

Second is an adjustment to the position of the transition between the Lower Warsash and Hamble terraces to the south of Warsash. The results of a GPR survey in the Warsash area suggests that in some places the transition is further to the south than is suggested by previous mapping schemes (Hatch 2014; Hatch et al. in revision.). In particular, an area mapped as the Hamble Terrace immediately west of Warsash Common has a bedrock-gravel contact height that is more consistent with the Lower Warsash Terrace. A second patch of gravel immediately south of Warsash Common can also be assigned to the Lower Warsash Terrace rather than the Hamble Terrace on the basis of surface height, which, at $15 \mathrm{~m}$ OD, matches the Lower Warsash Terrace surface height elsewhere in the area. The presence of a gravel pit in this area (Newbury's Pit - see below) makes this an important change for understanding the Warsash archaeology.

The terrace mapping employed in this paper is that of Hatch (2014; Hatch et al. in revision), using the terrace nomenclature proposed by Westaway et al. (2006) and subsequently modified by Harding et al. (2012).

\section{Chronology of the Warsash Terraces}

Recent OSL dating programmes have provided age estimates for the terrace gravels in the Warsash area. Briant et al. (2012) sampled sand layers within the Hamble Terrace gravels exposed in the cliffs between Solent Breezes Caravan Park and Brownwich Lane, providing an MIS 7 age estimate for that terrace aggradation. They argue that this indicates aggradation to have occurred during a cold sub-stage of MIS 7, although Harding et al. (2012) suggest this may be a slight overestimate and should be revised to MIS 6 based on the uplift modelling of Westaway et al. (2006). Hatch (2014; Hatch et al. in revision.) sampled sand layers within the Lower Warsash Terrace deposits revealed in sections excavated at Warsash Common and Hamble Park (Fig. 1), two of the former Warsash gravel pits. Hatch argues that the resulting OSL age estimates suggest terrace aggradation during MIS 8, which may indicate the associated archaeology is derived from sediments deposited during the preceding MIS 9 interglacial. Harding et al. (2012) obtained an OSL age estimate for the Mottisfont Terrace at Dunbridge that suggests terrace aggradation during MIS 8/9. If these OSL dates are broadly correct, then they indicate contemporaneity of the two terrace fragments, thereby providing further support for a younger age for the Lower Warsash Terrace than the Belbin Terrace in the Dunbridge area.

\section{Methods}

The analysis of the Warsash Palaeolithic record is underpinned by a detailed study of all available contextual information, including historic mapping, journal articles and artefact labels, in order to determine an accurate provenance for as much of the Warsash record as possible. The history of quarrying in the area is recorded and digitised from successive editions of the 1:10,560 County Series (Hampshire Sheet), 1:10,560 Imperial Edition and 1:10,000 National Grid Ordnance Survey mapping. The Terrace mapping is based on the 1:50,000 Digital Geological Map of Great Britain (BGS 2009) with modifications by Hatch (2014). Relevant collections were initially identified from the Southern Rivers Palaeolithic Project (SRPP; Wessex Archaeology 1993) database. All this information was integrated and explored using Esri ArcMap 10.2.2.

The nature of the Warsash record meant lithic analysis was restricted to the study of handaxes and Levallois artefacts. Methods for recording taphonomic attributes were adapted from Ashton (1998). Where stratigraphic information is absent, artefact condition is used to predict the likely geological context, where rolled artefacts are likely to have been recovered from the terrace 
sands and gravels, while fresh artefacts may have been recovered from fine-grained sediments overlying the terrace deposits. Two typological schemes were used to record the handaxes (Roe 1968; Wymer 1968) alongside the recording of a suite of standard taphonomic, metric and technological attributes. The Levallois material was recorded following Scott (2010).

\section{The Warsash Palaeolithic archaeology}

The Southern Rivers Palaeolithic Project (SRPP; Wessex Archaeology 1993) lists a total of 609 Palaeolithic artefacts from Warsash, including 478 handaxes and 24 Levallois artefacts, from 15 separate sites. The majority of these ( 475 artefacts including 366 handaxes and 11 Levallois artefacts) are listed as a general entry for the Warsash area. There appear to be at least two duplications in the SRPP database: one handaxe from Dibles Pit appears twice, as does a collection of 29 handaxes from the former pit at Solent Breezes, listed as both Chilling Church Pit and Hook-Chilling Pit. Since the SRPP database was produced, 51 handaxes in a private collection were loaned to Hampshire Cultural Trust for study and can be added to the total number of known handaxes, producing a total of 499 handaxes (Table 3). An additional ten Warsash Levallois artefacts have been identified in collections that were not listed by the SRPP, bringing the known total to 34 . For this study, 497 artefacts including 381 handaxes, 19 Levallois flakes and 5 Levallois cores were located and recorded. It is these three artefact types that are examined below.

\subsection{The provenance of the Warsash artefacts}

A common problem for studies of secondary context Palaeolithic archaeology is the lack of associated contextual information, reflecting the disparate and, in many cases, limited recording methods of the multitude of professional and amateur collectors responsible for the record. This has been highlighted as a particular problem for the Solent (Ashton et al. 2011). Recent research has identified a number of previously unknown collector catalogues and notebooks, which, in conjunction with analysis of historic map data and other sources of contextual information, enabled an accurate provenance to be established for substantial portions of the Solent archaeological record (Davis 2013, 2014). However, in the case of Warsash, no detailed collector records were discovered, and in most cases collectors did not record the specific pit from which artefacts were recovered.

While Burkitt et al. (1939) did not provide locations for Mogridge's four pits, Parkes (1947) did so in his brief report of an assemblage of later prehistoric pottery recovered from the same pits. He stated that if Fleet End is considered as the centre of the 'site', then Button's Pit and New Pit are to the west, Dyke's Pit is to the south, Newbury's Pit is to the south-east, and an unnamed disused pit is to the north. Figure 4 shows the area between Warsash and Hook described by Burkitt et al. (1939) as it was mapped in 1942. At this time there were four large gravel pits that are likely candidates for Mogridge's four pits, plus three smaller pits. Parkes' (1947) description indicates that the large pits to the west and south-west, in the area that is now Warsash Common, are New Pit and Dyke's Pit respectively, the large pit to the south-east is Newbury's Pit and the pit to the north is the unnamed disused pit, which, by process of elimination, must be Park's Pit. The small pit to the east is the initial workings at Fleet End, leaving two other small pits as candidates for Button's Pit. The information provided by Parkes (1947) contradicts much of the locational information supplied by the SRPP; the latter is provided without sources and appears to be incorrect.

[Figure 4 - full width - colour online only]

The location of Newbury's Pit is confirmed by information recorded on the artefacts of the Draper Collection held at Portsmouth Museum. Draper wrote a six digit grid reference on each of the artefacts, presumably indicating the location from which they were recovered. On three artefacts 
he also recorded the name of a pit, Newbury's Pit, alongside the grid reference (509056), which corresponds with the location discussed above. Newbury's Pit was situated in the area of terrace gravels to the south of Warsash Common that has been reinterpreted as belonging to the Lower Warsash Terrace (Hatch 2014; in revision). The grid references on the remainder of the artefacts indicate that Draper collected 10 handaxes from Park's Pit, seven handaxes and four Levallois flakes from New Pit, and two handaxes from Fleet End Pits. These can be added to the small number of other artefacts for which a specific pit is recorded (Table 3).

[Table $3-3 / 4$ width]

Although only a small portion of the Warsash record can be assigned to specific pits, the information outlined above enables a substantial number of the artefacts with general provenances to be assigned to a specific terrace, be that from within the terrace body or from overlying sediments. As all of the pits listed by Burkitt et al. exploited Lower Warsash gravels, all the artefacts of the Mogridge Collection recovered prior to 1939 can be assigned to the Lower Warsash Terrace. Furthermore, using historic mapping to chart the development of quarrying in Warsash (Fig. 5), it appears that all quarries in the area prior to 1945 exploited only Lower Warsash Terrace deposits. This provides an indication of the likely source of any Warsash artefacts that can be proven to have been recovered prior to 1945 . On this basis, 254 Warsash handaxes and 30 Levallois artefacts can be assigned to the Lower Warsash Terrace (Table 3), with the potential for more to be added from any material not studied here. Matters are less clear for artefacts discovered after 1945, since the next edition mapping shows substantial gravel extraction in both the Hamble and Lower Warsash terraces, and although by 1968 the majority of extraction is focused south of Warsash in the Hamble Terrace, both terraces continue to be exploited. Thus, any artefacts with a general Warsash provenance recovered after 1945 may be related to either the Hamble Terrace or the Lower Warsash Terrace. In the case of the handaxes, where a substantial number cannot be assigned to either terrace, the Hamble Terrace may therefore be underrepresented. This is not the case for the Levallois artefacts. All of the Levallois artefacts that can be assigned to a specific terrace are associated with the Lower Warsash Terrace. The impression here is that the contrasting number of Levallois artefacts between the Hamble and Lower Warsash terraces is real, as there are just four Levallois artefacts that cannot be assigned to either terrace. The key question for the Levallois material is therefore the nature of its relationship to the Lower Warsash Terrace deposits and the associated handaxe assemblage.

[Figure 5 - full width - colour online only]

\subsection{Geological context of the Warsash artefacts}

Given the condition of the Warsash artefacts, there is little doubt that the majority was recovered from the sands and gravels that form the terrace bodies. In general, the Warsash handaxes are in a range of conditions trending towards very rolled (Fig. 6) and stained and with a wide range of different handaxe types represented (see below). This suggests a mixed assemblage formed of material derived over a range of distances upstream, including some that are likely to have been reworked from higher terrace fragments and some that may have been discarded in the immediate vicinity of Warsash. This is supported by the observations of Burkitt et al. (1939), who state that two of the three handaxe groups they recognised at Warsash were recovered from the lower ferruginous gravel. There is some variation in the degree of rolling between the two terraces, with handaxes from the Hamble Terrace being typically more rolled than those from the Lower Warsash Terrace. This mirrors broader patterning in the Solent, where an increase in rolling from higher to lower terraces is taken to represent the cumulative effect of handaxes reworked from older to younger gravels (Ashton and Hosfield 2010; Davis 2013). The general Warsash assemblage displays a similar degree of rolling as the Lower Warsash Terrace 
assemblage, which may suggest that many of these handaxes are also from the Lower Warsash Terrace.

[Figure $6-1 / 2$ width - colour online only]

The geological context is less certain for a small number of handaxes in fresh condition. While some of these could have been recovered from within the terrace body, it is also possible that their condition is indicative of their origin in a fine-grained deposit overlying the terrace sediments. This is likely to be the case for at least one of these, a bout coupé discovered at Hook by John Evans in 1876. This is a characteristic tool type of Late Middle Palaeolithic occupation during the Devensian (White and Jacobi 2002) and therefore is likely to post-date terrace formation, and is perhaps related to the brickearth deposits in the Hook area.

[Figure 7 - full width - colour online only]

The stratigraphic context of the Levallois artefacts is less clear, particularly in light of the contradictory nature of the observations by Burkitt et al. (1939) and Shackley (1978; see above). Artefact condition is key to resolving the relationship between the handaxe and Levallois assemblages at Warsash. Previous observations have drawn a distinction between the typically rolled and stained handaxes and the fresher, more patinated condition of the Levallois artefacts (Burkitt et al. 1939; Shackley 1978; Ashton and Hosfield 2010). Analysis of the condition of 243 handaxes and 20 Levallois artefacts associated with the Lower Warsash Terrace confirms this pattern (Fig. 7), suggesting that the two assemblages have distinct taphonomic histories. As discussed above, the rolled and stained condition of the handaxes is typical of material from terrace gravels. For the Levallois material it is not possible to be quite so categorical. The frequent patination may be indicative of sub-aerial exposure of the Levallois material on the surface (Burroni et al. 2002), although further research is still required to fully understand the chemical processes involved (Glauberman and Thorson 2012). What seems certain is that the majority of the Levallois artefacts originated in a different context to the majority of the handaxes. This could be (1) an upper portion of the terrace gravels that is finer and less iron-rich, (2) the surface of the terrace gravels, or (3) an overlying sediment.

\subsection{The Warsash handaxes}

In total, 246 handaxes from the Lower Warsash Terrace, 16 from Hamble Terrace and 119 general Warsash handaxes have been recorded for this study (Table 4, Fig. 8). The majority $(96.3 \%)$ are made on flint, with the remainder manufactured on Greensand chert. It is likely that the principal raw material source was local river gravels. These may have been particularly abundant at the Test-Itchen and Test-Solent confluences, which at the time of Hamble Terrace and Lower Warsash Terrace aggradation were approximately $10 \mathrm{~km}$ north and $2 \mathrm{~km}$ south of Warsash respectively. It is probable that the chert was sourced from Solent gravels where it is much more common than in the Test (Allen and Gibbard 1993; Harding et al. 2012). This is reflected in the raw material characteristics of the Solent, Stour and Test handaxe assemblages, with chert handaxes much rarer among the latter (Davis 2013).

[Figure 8 - full width - colour online only]

Pointed handaxes are the most common in all three groups and combine with sub-cordates to account for more than half of the Warsash handaxes (Table 4). Cordates and ovates are rarer, accounting for just over $20 \%$. All of the other major handaxe types are present in small numbers, including the bout coupé described above. Ficrons (Fig. 8a,c) and cleavers (Fig. 8b) are present in the Lower Warsash Terrace and general groups, but ficrons are absent from the small Hamble Terrace assemblage.

[Table 4 -3/4 width] 
Of the 217 Warsash handaxes for which a blank type can be determined, $17.5 \%$ are manufactured on flakes, with the remainder made on river cobbles or nodular flint. The use of flake blanks is a feature of the Lower Warsash Terrace assemblage in particular, and at the very least indicates the presence of raw material suitable for the production of flakes large enough to be used as handaxe blanks. Two handaxes from the Lower Warsash Terrace and one from the general assemblage have been formed through unifacial working of the dorsal surface, leaving the ventral surface unworked. Many of the others have only minimal working to the ventral surface, typically focused on the removal of the striking platform and bulb of percussion, presumably to maximise the length of the cutting edge.

One potential outcome of the greater working to the dorsal face of a flake blank is the production of a handaxe with a plano-convex profile. This is the case for 19 of the Warsash flake handaxes, including both examples illustrated by Burkitt et al. (1939: Fig. 8). These form part of a larger number of handaxes $(n=44)$, distributed evenly across the three Warsash handaxe groups, with either a pronounced or partial plano-convex profile. In most cases, the profile is clearly a reflection of the original morphology of the raw material blank, be that a flake (e.g. Fig. 8e), split cobble, or simply a cobble/nodule with a natural flat surface identifiable from remnant cortex (e.g. Fig. 8d). There are four examples that exhibit evidence for the imposition of this form through the flaking process. In these cases a final phase of non-invasive flaking was applied to the convex face. With reference to similar cases at Wolvercote, Ashton (2002) argues that a plano-convex profile is the natural outcome of such a process, as the final trimming to one face gives it a steeper angle to the cutting edge. In all of these cases, it remains uncertain whether the plano-convex profile was deliberately imposed by the knapper, or was an unintended byproduct of the original form of the raw material or of a particular manufacturing/resharpening process.

One further characteristic of the Warsash handaxes described by Burkitt et al. (1939) is the modification of the cutting edges, particularly in the form of notches. However, the current study found no convincing evidence for such behaviour. Edge modification on all but one of the handaxes examined is most likely to result from inter-clast collisions during fluvial reworking, an interpretation supported by the rolled nature of these handaxes. One large pointed handaxe described by Burkitt et al. does have opposing knapped notches in its lateral edges, however the freshness of the removals and the condition of the resulting surfaces suggests these were made after they were excavated, although for what purpose is unclear.

The large number of handaxes attributable to the Lower Warsash Terrace warrants a more detailed examination of their taphonomy, typology (Table 5) and technology (Table 6). There is a correlation between the degree of rolling and the degree of staining, where the more rolled handaxes are typically more stained than the less rolled handaxes (Fig. 7a). This suggests that the less rolled handaxes have been reworked over a shorter distance and have a different taphonomic history to the more rolled material. There are some typological differences between the handaxes in these different conditions. The less rolled and stained material is dominated by pointed and sub-cordate forms, with small numbers of most of the other types. The very rolled material that displays the greatest degree of staining shows a similar range of forms and pointed handaxes are again the most numerous, however cordates, ovates and crude pointed forms are much more frequent.

[Table $5-3 / 4$ width]

This matches some of the observations of Burkitt et al. (1939), who drew a taphonomic distinction between their Early Acheulean series with crude handaxes, their Middle Acheulean series with ovates, points, cleavers and hand-choppers, and the less rolled pointed handaxes of their Late Acheulean series. Burkitt et al. suggested that their Early and Middle Acheulean series originated in the lower ferruginous gravels. It is possible therefore that the more rolled 
and stained material studied here originated in these lower gravels, with the high level of rolling and typological heterogeneity indicative of the mixing of handaxes derived from a number of different occupation sites upstream from Warsash and from older terrace gravels. The less rolled and stained material is certainly more likely to be representative of handaxe manufacture in the vicinity of Warsash, and, while being in a condition still consistent with a secondary fluvial context, may even have been derived from a single local occupation site.

There are, however, a number of observations made by Burkitt et al. (1939) of the Lower Warsash Terrace handaxes that are not supported here. There is no taphonomic evidence to support the distinctions between their Early and Middle Acheulean series, an interpretation that would seem to be derived from contemporary views of technological evolution (Oakley 1958). The "shapely coup-de-poing, made on flakes" and chert handaxes (Burkitt et al. 1939:40) that they use to characterise their Late Acheulean series are found in a range of conditions from very to slightly rolled. This suggests that the use of chert and the use of flake blanks for production of pointed handaxes at Warsash are not exclusively part of a chronologically distinct handaxe tradition as proposed by Burkitt et al., instead being more general aspects of the handaxe technology represented at Warsash.

The very rolled Lower Warsash Terrace handaxes are notably smaller on average than the rolled and slightly rolled material. This in part may reflect the greater loss of mass to this group through inter-clast collisions during fluvial reworking, but may also be a function of the group's typological composition. The variation in elongation, edge shape and profile shape also supports the typological variation discussed above, where the very rolled group, with its greater number of cordates and ovates, is characterised by a lower mean elongation, more rounded edge shapes and more lenticular profiles.

[Table 6 - full width]

The mean values and frequencies of attributes related to reduction strategy do not fit so well with expectations derived from the typological data. Typically it would be expected that an assemblage with a greater proportion of ovates would have a longer mean cutting edge, a larger mean scar index and low mean cortex retention. This may hold true for the rolled and very rolled groups, however the characteristics of the slightly rolled group confound these expectations, having relatively low cortex retention, long cutting edges and a high scar index despite being dominated by pointed handaxes. It is possible that these may be characteristics of a local knapping tradition that included the relatively intensive reduction of large flint and chert cobbles to produce large pointed and sub-cordate handaxes. This contrasts the more mixed and more rolled assemblages that sample handaxe manufacture over a greater area and probably over a greater period of time.

\subsection{The Warsash Levallois artefacts}

Of the 34 Levallois artefacts known to have been discovered at Warsash, 24 have been located and recorded for this study (Fig. 9). These are formed of five cores and 19 flakes, all of which are associated with the Lower Warsash Terrace except one core and three flakes that are part of the general Warsash assemblage. As described above, the majority are fresh or slightly rolled and patinated (Fig. 7b), and they are all manufactured on flint. Technologically, they form a cohesive group, characterised by centripetal surface preparation, lineal removals and facetted striking platforms. However, there are some exceptions that point to a degree of variation in both surface preparation and exploitation methods. The dorsal scar patterns of two of the flakes suggest unipolar and bipolar flaking was occasionally employed to prepare the flaking surface, while one of the cores displays the removal of relatively small flakes through a centripetal exploitation method. 
[Figure 9 - full width - colour online only]

\section{Discussion}

Recent work at Warsash by Hatch (2014; Hatch et al. in revision.) and presented in this paper has advanced understanding of the relationship between the fluvial terraces in the Warsash area and the broader River Test terrace sequence, the age of terrace aggradation and the distribution and character of the related archaeological record. Three main terraces can now be recognised in the Warsash area, the Upper Warsash, Lower Warsash and Hamble terraces; the last two have produced the rich archaeological record. The Warsash archaeology is therefore related to terrace deposits that are stratigraphically lower than the artefact-rich Belbin Terrace deposits at Romsey and Dunbridge. Recent OSL dating work on the Test terraces suggests that the Hamble Terrace formed during MIS 7 (Briant et al. 2012) and the Mottisfont Terrace / Lower Warsash during MIS 8 (Harding et al. 2012; Hatch et al. in revision.). The Warsash Palaeolithic record can be divided into three key groups. These are (1) the typically rolled and stained, handaxe-dominated assemblage recovered from the Lower Warsash Terrace deposits, (2) the small Levallois assemblage also associated with the Lower Warsash Terrace but likely to be younger than the handaxes on technological and taphonomic grounds and (3) the typically rolled and stained, handaxe-dominated assemblage recovered from the Hamble Terrace deposits. A fourth group is formed of the general Warsash material that cannot be assigned to a specific terrace.

\subsection{The age of the Warsash Palaeolithic archaeology}

\section{Group 1}

The rolled and stained condition of many of the Lower Warsash Terrace handaxes and the observations of Burkitt et al. (1939) suggest that much of the Lower Warsash Terrace handaxe assemblage was recovered from the basal gravels. It is likely that these have been reworked from older deposits, and therefore may represent handaxe manufacture during the preceding MIS 9 interglacial. They are comparable to other Lower Warsash Terrace and Mottisfont Terrace handaxe assemblages that are characterised by high degrees of rolling and staining, such as Kimbridge Pit, Colden Common and the series of Mottisfont / Lower Warsash Terrace sites in Southampton (Wessex Archaeology 1993; Davis 2013). The small number of fresher, less stained Lower Warsash Terrace handaxes clearly have a different taphonomic history to the majority. That these are also typologically and technologically distinct at the assemblage-level suggests that they are not merely handaxes derived over shorter distances and/or shorter periods of time, but represent a spatially and temporally discrete phase of handaxe manufacture in the immediate vicinity of Warsash, characterised by the production of large, intensively flaked pointed and sub-cordate handaxes. Recent analysis of the handaxe assemblage excavated at Harnham, Wiltshire, suggests the presence of handaxe technology in the Solent region during milder sub-stages of MIS 8 (Bates et al. 2014; see Pettitt and White 2012 for an alternative interpretation). It is possible that the fresher Lower Warsash Terrace handaxes at Warsash are part of the same phenomenon, although they may also be derived from older MIS 9 deposits along with the more rolled material.

\section{Group 2}

The age of the Warsash Levallois material is uncertain. Although it is associated with the Lower Warsash Terrace, the condition of the Levallois artefacts suggests that they originated from a different context than the majority of the Lower Warsash Terrace handaxes, be that from a higher portion of the terrace gravels, from their surface, or, as suggested by Burkitt et al. (1939) from overlying sediments. A parallel can be drawn with some of the Middle Thames Levallois sites, such as at Creffield Road and Yiewsley (Scott et al. 2011). Here, Levallois assemblages 
are also typically fresh and patinated and contrast the rolled and stained condition of the handaxes recovered from the gravels (ibid.). The condition of the Levallois material combined with Brown's $(1889,1895)$ observations regarding its stratigraphic position suggests that it is derived from sediments overlying the Lynch Hill gravels and probably originate from the surface of the gravel deposits (Ashton et al. 2011). This suggests that the artefacts were either discarded on the margins of the floodplain after aggradation but before downcutting during late MIS 8, or discarded after downcutting on the surface of the newly formed Lynch Hill terrace during MIS 7 or later (Ashton et al. 2003). If the same situation is found at Warsash, then the Levallois material may have been deposited on the floodplain margins after the aggradation of the Lower Warsash Terrace deposits but before downcutting, possibly during late MIS 8, or post-downcutting on the Lower Warsash Terrace surface adjacent to the new floodplain.

\section{Groups 2 and 3}

So what is the relationship between the Warsash Levallois material and the handaxes recovered from the Hamble Terrace? Although only a small number of Warsash handaxes can be attributed to this terrace, the large numbers of handaxes discovered at Lee-on-Solent and Hill Head (Wessex Archaeology 1993), both located on the eastern flank of Southampton Water to the south of Warsash, indicate a broadly comparable archaeological richness to the Lower Warsash Terrace. On the face of it this is surprising, given the likely MIS 7 age of the Hamble Terrace, a time frame typically associated with Middle Palaeolithic technology. This could lend weight to the proposal that the Early Middle Palaeolithic of the Solent was characterised by the continuance of handaxes as a major part of lithic technology (Ashton and Hosfield 2010). However, the fact that much of the Hamble Terrace material was recovered from the shore of Southampton Water beneath the exposures of the Hamble Terrace in the cliffs creates some uncertainty over their provenance, as it is possible that some were eroded from higher terrace gravels upstream and washed on to the beach. Further, as the Hamble Terrace handaxes are typically more rolled than those from the Lower Warsash Terrace, it is more likely that the artefacts are reworked from older terrace deposits. The high degree of rolling hinders their use as evidence for an even later occurrence of handaxe technology than identified at Harnham and the existence of a technological tradition that includes Levallois and handaxe manufacture.

\subsection{Handaxe typology}

Discussion of Warsash in the Palaeolithic literature is predominantly in relation to handaxe typology, specifically the presence of particular handaxe types that may be of chronological significance. Roe $(1981,2001)$ highlighted the presence of ficrons, cleavers and plano-convex handaxes at Warsash, features of the Warsash Palaeolithic record, and the Lower Warsash Terrace record in particular, confirmed by the current study. The appearance of these types in significant proportions, and, in the case of the former two, their appearance in combination, has been argued to be characteristic of some British handaxe assemblages manufactured between MIS 10 and MIS 8 (Roe 1981, 2001; Wenban-Smith 2004; Pettitt and White 2012; Bridgland and White 2014; White 2015). The dating of Warsash discussed above places much of the Warsash material within this timeframe. However, cleavers and ficrons occur throughout the British Lower Palaeolithic (Bridgland and White 2014). As they form a small proportion of the Warsash handaxes it remains unclear whether they represent a wider chronologically discrete tradition of handaxe manufacture or are simply part of the range of handaxe forms that can occur in a mixed Lower Palaeolithic assemblage.

2002) argues that plano-convex handaxes are the product of specific resharpening practises aimed at extending the use-life of a handaxe. Similarly, White (2006) argues that cleavers are products of particular resharpening techniques and it is conceivable that ficrons can also be explained in this way. White suggests that resharpening may have become a more frequent 
practise during MIS 9 and, given the dating discussed above, it is possible that all three of these types at Warsash are an expression of this.

\subsection{The Early Middle Palaeolithic of Southern Britain}

The small assemblage of Levallois artefacts from the Lower Warsash Terrace forms a significant part of the Levallois record from the Solent region. The precise numbers of Levallois artefacts from the region is unclear, with recent estimates varying between 67 (Ashton and Hosfield 2010) and 129 (Wessex Archaeology 1993). One issue is the difficulty of identifying the mode of production of isolated flakes, since characteristics typical of Levallois flakes, such as facetted platforms and organised dorsal scar patterns, also occur occasionally on flakes related to the latter stages of handaxe manufacture. Whatever the number, the record is remarkably small, both in comparison to the rich handaxe record from the Solent and the Levallois record of the Thames Valley (Ashton and Hosfield 2010; Ashton et al. 2015).

[Table 7 - full width]

The Solent Levallois record can be divided into three groups: simple prepared cores (or protoLevallois), rolled Levallois cores and flakes, and fresh Levallois cores and flakes (Table 7). Simple prepared cores have been identified at three sites: Dunbridge in the Test Valley (Belbin Terrace; Harding et al. 2012), and Harvey's Lane Gravel Pit (West Southbourne Terrace) and East Howe Brixey and Good's Pit (Knighton Lodge Terrace) in Bournemouth (Davis 2013). All seven cores are rolled and stained, mirroring the condition of the majority of the handaxes recovered from the same sites, which may indicate a similar context for the two artefact types.

Evidence for the relationship between the simple prepared cores and fully developed Levallois is sparse and contradictory. On the basis that rolled artefacts are likely to derive from the terrace gravels, the presence of two rolled Levallois flakes at Brixey and Good's Pit and three isolated flakes recovered from Belbin / Upper Warsash Terrace gravels in the Test suggests similar contexts for the simple prepared cores and fully developed Levallois at these sites. However, the fact that these artefacts may have very different taphonomic histories demands caution when interpreting their apparent similarities in condition, as does the previously mentioned difficulties in identifying Levallois technology from single flakes. In Bournemouth the occurrence of rolled Levallois artefacts in the Ensbury Park Terrace suggests they pre-date the simple prepared cores, although the high levels of rolling among the Knighton Lodge Terrace and West Southbourne Terrace assemblages means that many of those apparently later artefacts may have been reworked from older terraces (Davis 2013). At Dunbridge the evidence suggests the simple prepared cores pre-date the fully developed Levallois, the latter being fresh and associated with the younger Mottisfont Terrace (Harding et al. 2012). The lack of clarity is unsurprising given the very small numbers of artefacts in question, as a few isolated examples of simple prepared cores do not necessarily represent a discrete technological tradition that is a precursor to fully developed Levallois technology.

Establishing the timing of the first appearance of fully developed Levallois in the region is equally difficult, not least because of the uncertain dating of many of the terraces. In the Test, the three isolated rolled flakes from the Belbin / Upper Warsash Terrace warrant caution, and it is potentially in the Lower Warsash Terrace, where two rolled Levallois cores occur, that the technique first appears. This would suggest a first appearance during MIS 9 or 8 , which is broadly contemporary with the earliest Levallois technology in the Thames (Bridgland 1994; White and Ashton 2003). In Bournemouth, rolled Levallois cores occur in the Ensbury Park Terrace, the richest of the Bournemouth terraces for both Levallois and handaxes. Allen and Gibbard (1993) correlate the Ensbury Park Terrace with the Taddiford Farm Terrace of the Western Solent, which, in light of the MIS 8/7 OSL age estimate for the younger Stanswood Bay Terrace (Briant et al. 2006), could suggest a MIS 9/8 age for the formation of the Ensbury Park 
Terrace. If correct, this suggests that Levallois technology first appeared across the Solent region at broadly the same time. With regards to the fresh Levallois material, if the argument for the context of the Warsash Levallois presented above is extended to the rest of the Solent region, it is possible that they are broadly contemporaneous despite their association with different terraces, representing a general scatter of Early Middle Palaeolithic artefacts across the landscape, potentially during late MIS 8/MIS 7.

There is not enough data at present to develop a clear picture of the introduction and development of the Levallois technique in the Solent. There are hints that it mirrors the evidence from the Thames Valley in terms of timing, with first appearance occurring during MIS $9 / 8$, possibly including simple prepared core technology. However, the rarity of Levallois artefacts relative to the Thames raises important questions about the nature of Early Middle Palaeolithic occupation in southern Britain. Whereas the Thames record reveals the replacement of handaxes by Levallois artefacts as the principal component of lithic technology (White and Jacobi 2002; White et al. 2006, 2011; Scott 2010; Pettitt and White 2012), the limited Levallois record and chronological challenges makes the nature of contemporary occupation elsewhere in Britain less clear.

So why are Levallois artefacts so rare in the Solent record? There are three possible answers, each with different implications for the nature of Early Middle Palaeolithic occupation in Britain. First, the paucity of the Solent Levallois record reflects preservation and recovery bias and is therefore unrepresentative of the actual density of Levallois artefacts discarded in the region; second, the scarcity of Levallois is representative of low density occupation of the Solent during the Early Middle Palaeolithic compared to the Thames (Pettitt and White 2012; Ashton et al. 2015); and third, human populations in the Solent continued to employ a technological system focused on handaxe manufacture in which Levallois technology only played a minor role (Ashton and Hosfield 2010; Ashton et al. 2011; Bates et al. 2014).

It is clear that the disparate preservation of Pleistocene sediments, the unsystematic exposure of sediments through quarrying, urban expansion and infrastructure development, and the biases introduced by the collectors have played important roles in shaping the Solent Palaeolithic record (Hosfield 1999). However, these are factors that characterise the fluvial archive in general, including the Thames, and are therefore not enough to explain the relative paucity of the Solent Levallois record when compared to the Thames. The key question is therefore are there any differences in the geological context or the mode of recovery of the Solent and Thames Palaeolithic archaeology that can explain the differences in the two records? With regards to the nature of discovery and recovery, the two records are very similar. Both are largely a result of antiquarian collecting activities at gravel pits and urban/infrastructure development sites during the late 19th and early 20th centuries (Wessex Archaeology 1993, 1996). As such, there is no reason to think that the nature of the commercial activities or the behaviour of the antiquarians in either region varied in any significant way that could create major differences in the two archaeological records.

In general, there are close parallels between the terrace sediments of the Solent and the Middle Thames. Both are typically characterised by thick gravel deposits with occasional sand lenses and an absence of interglacial deposits preserved within the terrace body. Any artefact-bearing fine grained deposits are more likely to overlie the terrace deposits and the archaeology within then post-dates gravel aggradation. As discussed above, much of the Levallois material from the Solent and the Middle Thames is likely to have originated in such deposits. The rare instances of interglacial deposits in the Solent, such as at Pennington Marshes and Lepe Country Park, were deposited in estuarine conditions during the last interglacial (MIS 5e) and have produced no archaeology (Briant et al. 2009). 
The situation in the Lower Thames is more complex as sedimentation and terrace formation is influenced by high sea-level stands, resulting in the build-up of thick fine-grained estuarine deposits (Gibbard 1994; Lewis et al. 2004). Fragments of these survive as terrace features, thereby increasing the potential for preservation of artefact-bearing interglacial sediments. It is these sediments that have produced the rich Lower Thames Early Middle Palaeolithic record including Crayford (Scott et al. 2011) and West Thurrock (Schreve et al. 2006). It has been argued that the contrast in the stratigraphic context of Levallois assemblages between the Lower and Middle Thames represents different patterns of landscape use by Neanderthals occupying different parts of the river valley (Scott et al. 2011). The evidence from the Solent suggests a similar pattern of landscape use to the Middle Thames.

Given the similarities in collecting history, terrace geology and artefact condition between the Middle Thames and the Solent, it is unlikely that preservation or recovery bias has played a significant part in the apparent disparity in the Early Middle Palaeolithic records between the two regions. This suggests that the explanation lies elsewhere, and is likely to reflect some differences in the nature of human presence between the two regions. A recent review of the geographical distribution of Middle Palaeolithic collections held at the British Museum by Ashton et al. (2015) revealed a clear concentration of Levallois sites and findspots in the Thames Valley relative to the rest of Britain (but see Pettitt and White 2012 for an alternative view on the distribution of Levallois material). Further, sites are more frequent in the lower reaches of the Thames and other rivers of eastern England than in the upper reaches. Ashton et al. (2015) argue that this pattern suggests that populations bearing Levallois technology entered Britain from the east across the southern North Sea area. Given the general absence of Levallois sites dated to the later stages of MIS 7, Ashton et al. suggest that occupation may have been shortlived, with populations becoming extinct as rising sea level cut off the British populations from mainland Europe. In this scenario, the impoverished Levallois record in the Solent relative to the Thames reflects the limited dispersal of these populations into the rest of southern Britain.

An alternative explanation is that the low density of Levallois artefacts in the Solent reflects regional differences in the technological repertoires of Early Middle Palaeolithic populations in southern and eastern Britain (Ashton and Hosfield 2010; Ashton et al. 2011). The apparent late occurrence of handaxes at Harnham (Bates et al. 2014) and the co-occurrence of handaxes and Levallois in MIS 7 deposits at Pontnewydd Cave in North Wales (Aldhouse-Green et al. 2012) suggests handaxe technology persisted into the Early Middle Palaeolithic in at least two places in Southern and Western Britain. Scott and Ashton (2011) highlighted a similar east-west divide in the Early Middle Palaeolithic of Northwest Europe, suggesting that the pattern in Britain may reflect different source areas for the British populations. The two major routes into Britain - across the Channel Basin and North Sea Basin - are likely to have permitted colonisation at different times and under different conditions (Ashton and Hosfield 2010). The greater depth of the Channel Basin would have caused it to be inundated earlier during phases of sea level rise, restricting access to cooler periods. Further, the Channel River would have presented a major obstacle to populations travelling into Britain across the Channel Basin.

It is of course possible that both of these scenarios have played a role in shaping the Early Middle Palaeolithic record of the Solent. The fresher Warsash handaxes might represent a similar persistence of handaxe technology to that identified at Harnham. This may represent the survival of MIS 9 populations during the relatively mild cold phases of MIS 8 (Bates et al. 2014) or human groups that entered Britain during a warmer phase of MIS 8 but at a time of relatively low sea levels that permitted a dryland crossing of the Channel Basin. Further, the cooccurrence of handaxes and simple prepared cores and Levallois artefacts in similarly rolled and stained conditions in the Lower Warsash Terrace in the Test and the Ensbury Park, West Southbourne and Knighton Lodge terraces in Bournemouth may point to a lithic technology around MIS 9/8 that incorporated both artefact types. Unfortunately, our understanding of the 
relationships between the different artefact types is limited by an absence of information relating to their stratigraphic context, and it is quite possible that they originated in sediments of different ages, and that the similarity in their condition simply reflects their exposure to similar postdepositional processes. However, there is no unequivocal evidence to suggest that the fresh Levallois artefacts from Warsash and the Solent more broadly are part of a technological repertoire that included handaxe manufacture. It seems more likely that these represent a relatively low intensity and/or short lived occupation of the region that is contemporary with the main phase of Early Middle Palaeolithic occupation in the Thames Valley.

\section{Conclusion}

Uncertainty over the provenance and context of Palaeolithic material is a common obstacle for studies dealing with old collections recovered from sand and gravel deposits of Pleistocene rivers. In many cases the uncertainty is a result of the inconsistency or absence of detailed records made by the collectors responsible for amassing the archaeological material. Problems are exacerbated when the site in question is known to encompass one or more gravel pits that exploited sediments of multiple terraces and ages. If artefacts cannot be assigned to a specific terrace body with a reasonable degree of certainty then they cannot be drawn into regional, national or global models of past human activity and must be excluded from any analysis. In previous studies in the Solent region Warsash has been excluded on this basis (Ashton and Hosfield 2010; Bates et al. 2004).

The work presented in this paper demonstrates that there may be more contextual information about a site than first meets the eye, or at least useful information can be gleaned if a thorough search of all available historical information is conducted. Of particular importance for Warsash is the information recorded on the artefacts themselves. The grid references written on some of the handaxes in the Draper Collection helps to pinpoint the locations of the key pits listed by Burkitt et al. (1939), while the date of recovery noted on many of the artefacts provides a chronology for the discoveries. Correlating this with the chronology of pit expansion understood via historic map regression allows a significant portion of the material with only a general Warsash provenance to be assigned to the Lower Warsash Terrace, thus enabling it to be examined within the framework of terrace stratigraphy.

The importance of Warsash for our understanding of the Lower and Early Middle Palaeolithic occupation history of Southern Britain can now be seen. The large number of handaxes from the Lower Warsash Terrace form an important record of the diversity of handaxe technology towards the latter stages of the Lower Palaeolithic, although the chronological significance of the small numbers of ficrons, cleavers and plano-convex handaxes present at Warsash remains uncertain. It does seem likely that the small but significant Levallois assemblage associated with the Lower Warsash Terrace is younger than the handaxe assemblage, potentially deriving from the surface of the gravels or from overlying sediments. Given the likely MIS 8 age for the formation of the Lower Warsash Terrace, these Levallois artefacts may represent Early Middle Palaeolithic occupation during MIS 7. There is no clear indication that these were part of a technological repertoire that included the continued use of handaxes. It is also possible that all of the fresh Levallois material from the Solent is broadly contemporary, representing a low density scatter of Early Middle Palaeolithic artefacts across the landscape. These may be contemporary to the main phase of Levallois technology in the Thames, and represent a limited dispersal of Neanderthal populations further into Britain from their entry route across the North Sea basin.

\section{Acknowledgements}

Specific thanks are extended to the other members of the Solent River Project, Becky Briant and Sven Lukas, for contributing to the broader research in which this study was conducted. 
Thanks must also be extended to the curators and staff at numerous museums for facilitating this work on the Warsash artefacts and to the two reviewers for their helpful comments and suggestions. This work was undertaken while RJD was in receipt of an Arts and Humanities Research Council Collaborative Doctoral Award (AH/1506837/1). This paper is a contribution to the Pathways to Ancient Britain Project funded by the Calleva Foundation.

\section{References}

Aldhouse-Green, S. H. R., Peterson, R., Walker, E. A. (2012). Neanderthals in Wales. Pontnewydd and the Elwy Valley Caves. Oxbow Books, Oxford.

Allen, L.G., Gibbard, P.L. 1993. Pleistocene evolution of the Solent River of southern England. Quaternary Science Reviews 12: 503-528.

Ashton, N. 1998. The taphonomy of the flint assemblages. In N. Ashton, S. G. Lewis, S. Parfitt (Eds.) Excavations at the Lower Palaeolithic Site at East Farm, Barnham, Suffolk, 1989-1994. British Museum Occasional Paper Number 125, London: pp. 183-204.

Ashton, N. M. 2001. One step beyond. Flint shortage above the Goring Gap: the example of Wolvercote. In: S. Milliken, J. Cook (eds.) A Very Remote Period Indeed: Papers on the Palaeolithic Presented to Derek Roe. Oxbow, Oxford, pp. 199-206.

Ashton, N., Hosfield, R. 2010. Mapping the human record in the British early Palaeolithic: evidence from the Solent River system. Journal of Quaternary Science 25: 737-753.

Ashton, N.M., Jacobi, R.M., White, M.J. 2003. The dating of Levallois sites in West London. Quaternary Newsletter 99: 25-32.

Ashton, N., Lewis, S.G., Harris, C.R.E. 2015. The distribution of early Palaeolithic sites in Britain. In N. Ashton, C. Harris (eds.) No Stone Unturned: Papers in Honour of Roger Jacobi. Lithic Studies Society Occasional Paper 9, London, pp. 19-30.

Ashton, N., Lewis, S. G., Hosfield, R. 2011. Mapping the human record: population change in Britain during the early Palaeolithic. In N. Ashton, S. G. Lewis, C. Stringer (eds.) The Ancient Human Occupation of Britain. Elsevier, Amsterdam, pp. 39-52.

Bates, M.R., Wenban-Smith, F.F., Briant, R.M., Marshall, G., 2004. Palaeolithic Archaeology of the Sussex/Hampshire Coastal Corridor, Project Number 3279. Unpublished Report for English Heritage.

Bates, M.R., Wenban-Smith, F.F., Bello, S.M., Bridgland, D.R., Buck, L.T., Collins, M.J., Keen, D.H., Leary, J., Parfitt, S.A., Penkman, K., Rhodes, E., Ryssaert, C., Whittaker, J.E. 2014. Late persistence of the Acheulian in southern Britain in an MIS 8 interstadial: evidence from Harnham, Wiltshire. Quaternary Science Reviews 101: 159-176. 
Briant, R.M., Bates, M.R, Schwenninger, J-L., Wenban-Smith, F. 2006. An optically stimulated luminescence dated Middle to Late Pleistocene fluvial sequence from the western Solent Basin, southern England. Journal of Quaternary Science 21: 507-523.

Briant, R.M., Bates, M.R., Boreham, S., Cameron, N.G., Coope, G.R., Field, M.H., Keen, D.H., Simons, R.M.J., Schwenninger, J-L, Wenban-Smith, F.F., Whittaker, J.E. 2009. Gravels and interglacial sediments at Stone Point Site of Special Scientific Interest, Lepe Country Park, Hampshire. In R.M. Briant, M.R. Bates, R.T. Hosfield, F.F. Wenban-Smith (eds.) The Quaternary of the Solent Basin and West Sussex Raised Beaches. Field Guide. Quaternary Research Association, London, pp. 171-188.

Briant, R.M., Bates, M.R., Marshall, G.D., Schwenninger, J-L., Wenban-Smith, F.F. 2012. Terrace reconstruction and long profile projection: a case study from the Solent river system near Southampton, England. Proceedings of the Geologists' Association 123: 438 - 449.

Bridgland, D. R. 1994. Quaternary of the Thames. Geological Conservation Review Series 7. Chapman and Hall, London.

Bridgland, D.R. 2001. The Pleistocene evolution and Palaeolithic occupation of the Solent River. In F.F. Wenban-Smith, R.T. Hosfield (eds.) Palaeolithic Archaeology of the Solent River: 15 25. Lithic Studies Society Occasional Paper 7. Lithic Studies Society, London, pp. 15-26.

Bridgland, D.R., White, M.J. 2014. Fluvial archives as a framework for the Lower and Middle Palaeolithic: patterns of British artefact distribution and potential chronological implications. Boreas 43: 543-555.

Bridgland, D.R., White, M.J. 2015. Chronological variations in handaxes: patterns detected from fluvial archives in north-west Europe. Journal of Quaternary Science 30: 623-638

British Geological Survey. 2009. Digital Geological Map of Great Britain 1:50 000 scale (DiGMapGB-50) data [CD-ROM]. Version 5.18. Keyworth, Nottingham: British Geological Survey. Tiles: EW298_Salisbury, EW299_Winchester, EW314_Ringwood, EW315_ Southampton, EW316_Fareham, EW320_Dorchester, EW321_Bournemouth, EW322_ Lymington, EW323_Portsmouth. Release date 30/11/2009.

Brown, J.A., 1889. Working sites and inhabited land surfaces of the Palaeolithic period in the Thames valley, etc. Transactions of the Middlesex Natural History and Science Society Session 1888-1889: 40-73.

Brown, J.A., 1895. Notes on the high-level river drift between Hanwell and Iver. Proceedings of Geologists Association 14: 153-173.

Burkitt, M.C., Paterson, T.T., Mogridge, C.J. 1939. The Lower Palaeolithic industries near Warsash, Hampshire. Proceedings of the Prehistoric Society 5: 39-50. 
Burroni, D, Donahue, R, Pollard, A., Mussi, M. 2002. The surface alteration features of flint artefacts as a record of environmental processes. Journal of Archaeological Science 29: 1277 1287.

Bury, H. 1923. Some aspects of the Hampshire plateau gravels. Proceedings of the Prehistoric Society of East Anglia 4: 15-41.

Bury, H. 1933. The plateau gravels of the Bournemouth area. Proceedings of the Geologists' Association 44: 314-335.

Davis, R. J. 2013. The Palaeolithic Archaeology of the Solent River: Human Settlement History and Technology. Unpublished PhD Thesis, University of Reading.

Davis, R. J. 2014. Concerning the earliest Acheulean occupation of Britain: the geological context of a handaxe assemblage from Foxholes, Bournemouth, southern England. Lithics: The Journal of the Lithic Studies Society 35: 33-39.

Edwards, R.A., Freshney, E.C. 1987. Geology of the country around Southampton. Memoir for 1:50,000 geological sheet 315 (England and Wales). HMSO, London.

Evans, J. 1872. The Ancient Stone Implements, Weapons and Ornaments of Great Britain. Longmans, Green, and Co., London.

Evans, J. 1897. The Ancient Stone Implements, Weapons and Ornaments of Great Britain (2nd Edition). Longmans, Green, and Co., London.

Gibbard, P.L. 1994. Pleistocene History of the Lower Thames Valley. Cambridge University Press, Cambridge.

Glauberman, P.J., Thorson, R.M. 2012. Flint patina as an aspect of "Flaked Stone Taphonomy": A case study from the loess terrain of the Netherlands and Belgium. Journal of Taphonomy 10: 21-43.

Harding, P. A. 1998. An Interim Report of an Archaeological Watching Brief on Palaeolithic Deposits at Dunbridge, Hants. In N. Ashton, F. Healy, P. Pettitt (eds.) Stone Age Archaeology: Essays in Honour of John Wymer: 72-76. Oxbow Monograph 102 and Lithic Studies Society Occasional Paper No. 6. Oxbow Books, London, pp. 72-76.

Harding, P, Bridgland, D. R, Allen, P, Bradley, P, Grant, M. J. Peat, D, Schwenninger, J-L, Scott, R, Westaway, R., White, T. S. 2012. Chronology of the Lower and Middle Palaeolithic in NW Europe: developer-funded investigations at Dunbridge, Hampshire, southern England. Proceedings of the Geologists' Association 123: 584 - 607.

Hatch, M. 2014. The Pleistocene Solent River and its Major Tributaries: Reinterpreting the Fluvial Terrace Stratigraphy as a Framework for the Palaeolithic Archaeology of the Region. Unpublished PhD Thesis, University of London. 
Hatch, M., Davis, R.J., Lewis, S.G., Ashton, N., Briant, B., Lukas, S. in revision. The stratigraphy and chronology of the Pleistocene fluvial sediments at Warsash, Hampshire, UK: implications for terrace stratigraphy and Palaeolithic archaeology of the River Test. To be submitted to Proceedings of the Geologist's Association.

Hosfield, R.T. 1999. The Palaeolithic of the Hampshire Basin. A regional model of hominid behaviour during the Middle Pleistocene. Archaeopress BAR British Series 286, Oxford.

Lewis, S.G., Maddy, D., Glenday, S. 2004. The Thames Valley sediment conveyor: fluvial system development over the last two interglacial-glacial cycles. Quaternaire 15: 17-28.

Oakley, K.P. 1958. Man the toolmaker. The Trustees of the British Museum, London.

Parkes, A. 1947. Some recent discoveries at Warsash. Proceedings of the Hampshire Field Club and Archaeological Society 16: 190 - 191.

Pettitt, P., White, M. 2012. The British Palaeolithic: Human Societies at the Edge of the Pleistocene World. Routledge, London.

Roe, D. A. 1968. British Lower and Middle Palaeolithic handaxe groups. Proceedings of the Prehistoric Society 34: 1-82.

Roe, D.A. 1981. The Lower and Middle Palaeolithic Periods in Britain. Routledge and Kegan Paul Ltd., London.

Roe, D. A. 2001. Some earlier Palaeolithic find-spots of interest in the Solent region. In F. F. Wenban-Smith, R. T. Hosfield (eds.) Palaeolithic Archaeology of the Solent River. Lithic Studies Society Occasional Paper No. 7, London, pp. 47-56.

Schreve, D. C., Harding, P., White, M. J., Bridgland, D. R., Allen, P., Clayton, F., Keen, D. H., Penkman, K. E. H. 2006. A Levallois knapping site at West Thurrock, Lower Thames, UK: its Quaternary context, environment and age. Proceedings of the Prehistoric Society 72: 21 - 52.

Scott, B. 2010. Becoming Neanderthals. Oxbow Books, Oxford.

Scott, B., Ashton, N. 2011. The Early Middle Palaeolithic: The European context. In N. Ashton, S. G. Lewis, C. Stringer (eds.) The Ancient Human Occupation of Britain. Elsevier, Amsterdam, pp. 91-112.

Scott, B., Ashton, N., Lewis, S. G., Parfitt, S., White, M. 2011. Technology and landscape use in the Early Middle Palaeolithic of the Thames Valley. In N. Ashton, S. G. Lewis, C. Stringer (eds.) The Ancient Human Occupation of Britain. Elsevier, Amsterdam, pp. 67-90.

Shackley, M.L. 1974. Stream abrasion of flint implements. Nature 248: 501-502.

Shackley, M. L. 1978. The behaviour of artefacts as sedimentary particles in a fluviatile environment. Archaeometry 20: 55-61. 
Tyldesley, J. 1986. The Wolvercote Channel Handaxe Assemblage. British Archaeological Report 153, Oxford.

Wenban-Smith, F. F. 2001. As represented by the Solent River: handaxes from Highfield, Southampton. In F. F. Wenban-Smith, R. T. Hosfield (eds.) Palaeolithic Archaeology of the Solent River. Lithic Studies Society Occasional Paper No. 7, London, pp. 57-70.

Wenban-Smith, F. 2004. Handaxe typology and Lower Palaeolithic cultural developments: Ficrons, cleavers and two giant handaxes from Cuxton. Lithics: The Journal of the Lithic Studies Society 25: 11-21.

Wessex Archaeology. 1993. The Southern Rivers Palaeolithic Project Report No. 1. 1991-1992, The Upper Thames Valley, the Kennet Valley and the Solent Drainage System. Wessex Archaeology, Salisbury.

Wessex Archaeology, 1996. The English Rivers Palaeolithic Project. Regions 7 and 10: North of Thames and Warwickshire Avon. Wessex Archaeology, Salisbury.

Westaway, R, Bridgland, D.R., White, M.J. 2006. The Quaternary uplift history of central southern England: evidence from the terraces of the Solent River system and nearby raised beaches. Quaternary Science Reviews 25: 2212-2250.

White, M.J. 1998. On the significance of Acheulian biface variability in Southern Britain. Proceedings of the Prehistoric Society 64: 15-44.

White, M.J. 2006. Axing cleavers: reflections on broad-tipped large cutting tools in the British Earlier Paleolithic. In: N. Goren-Inbar, G. Sharon (eds.) Axe age: Acheulian toolmaking from quarry to discard. Equinox, London, pp. 365-386.

White, M. J. 2015. 'Dancing to the rhythms of the Biotidal zone': Settlement history and culture history in Middle Pleistocene Britain. In Coward, F., Hosfield, R., Pope, M., Wenban-Smith, F. (eds) Settlement, Society and Cognition in Human Evolution: Landscapes in the Mind. Cambridge University Press, New York, pp. 154-173.

White, M. J., Jacobi, R. 2002. Two sides to every story: bout coupé handaxes revisited. Oxford Journal of Archaeology 21: 109 - 133.

Wymer, J.J., 1968. Lower Palaeolithic Archaeology in Britain as Represented by the Thames Valley. John Baker, London.

Wymer, J.J. 1999. The Lower Palaeolithic Occupation of Britain (Vol. 1 and 2). Wessex Archaeology and English Heritage, Salisbury. 


\begin{tabular}{|c|c|c|c|c|c|c|}
\hline \multirow[b]{2}{*}{ Collector } & \multirow[b]{2}{*}{$\begin{array}{l}\text { Museum } \\
\text { Collection } \\
\text { s }\end{array}$} & \multirow[b]{2}{*}{$\begin{array}{l}\text { Known years } \\
\text { active in } \\
\text { Warsash }\end{array}$} & \multicolumn{4}{|c|}{ Minimum Warsash Collection } \\
\hline & & & $\begin{array}{l}\text { Handax } \\
\mathrm{e}\end{array}$ & $\begin{array}{l}\text { Levalloi } \\
\mathrm{s}\end{array}$ & $\begin{array}{l}\text { Othe } \\
r\end{array}$ & $\begin{array}{l}\text { Tota } \\
\text { I }\end{array}$ \\
\hline J. Codrington & $\mathrm{BM}$ & - & 1 & - & - & 1 \\
\hline Henry Dewey & $\mathrm{BM}$ & - & 1 & - & - & 1 \\
\hline Chris Draper & PM & 1939-1952 & 24 & 4 & 16 & 44 \\
\hline Herbert Druitt & НCT & - & 1 & - & - & 1 \\
\hline A. R. Edwardson & BM, WM & $1948-1954$ & 11 & 1 & - & 12 \\
\hline Sir John Evans & $\mathrm{OA}$ & $1864-1877$ & 4 & 1 & - & 5 \\
\hline Rev. G. Langdon & WM & 1928-1932 & 33 & - & - & 33 \\
\hline Arthur Lloyd & HCT & - & 5 & - & 3 & 8 \\
\hline C. J. Mogridge & $\mathrm{BM}, \mathrm{PM}$ & 1928-1952 & 150 & 15 & 64 & 229 \\
\hline G. J. Sanding & WM & $1928-1935$ & 13 & - & - & 13 \\
\hline John Sharpe & PC & - & 51 & - & - & 51 \\
\hline William Allen Sturge & $\mathrm{BM}$ & $1876-1876$ & 1 & - & - & 1 \\
\hline
\end{tabular}

Table 1: Summary of Warsash collectors. Museum collections are British Museum (BM), Portsmouth Museum (PM), Hampshire Cultural Trust (HCT), The Ashmolean, Oxford (OA) and Winchester Museum (WM), plus one private collection (PC). Years active and minimum collection composition based on artefacts identified for this study.

\begin{tabular}{llll}
\hline \multirow{2}{*}{$\begin{array}{l}\text { (after Booth } \\
\text { 2002) }\end{array}$} & $\begin{array}{c}\text { Upstream terraces } \\
\text { (after Westaway et al. } \\
\text { 2006 and Harding et al. } \\
\text { 2012) }\end{array}$ & $\begin{array}{l}\text { (after Edwards \& } \\
\text { Freshney 1987 } \\
\text { and Hatch 2014) }\end{array}$ & $\begin{array}{l}\text { (after Westaway et al. 2006 } \\
\text { and Harding et al. 2012) }\end{array}$ \\
\hline \hline Terrace 1 & Broadlands Farm Terrace & Terrace 1 & Broadlands Farm Terrace \\
\hline$N^{*} \mathrm{~A}^{*}$ & Hamble Terrace & Terrace 2 & Hamble Terrace \\
\hline \multirow{2}{*}{ Terrace 2/3 } & Mottisfont Terrace & Terrace 3 & Lower Warsash Terrace \\
\cline { 2 - 4 } & Belbin Terrace & Terrace 4 & Upper Warsash Terrace \\
\hline N/A & Ganger Wood Terrace & Terrace 5 & Mallards Moor Terrace \\
\hline Terrace 4 & Nursling Terrace & Terrace 6 & Nursling Terrace \\
\hline Terrace 4 \& 5/6 & Bitterne Terrace & Terrace 7 & Bitterne Terrace \\
\hline Terrace 5/6 & Midanbury Terrace & Terrace 8 & Rownhams Farm Terrace \\
\hline
\end{tabular}

Table 2: Revised correlations by Hatch (2014; Hatch et al. in revision) between upstream Test terraces in the vicinity of Dunbridge and Romsey as mapped by Booth (2002) and the downstream terraces in the Warsash area as mapped by Edwards and Freshney (1987). Terrace nomenclature after Westaway et al. (2006; Harding et al. 2012). *Hamble Terrace and Ganger Wood / Mallards Moor Terrace are not preserved in the area mapped by Booth (BGS Sheet 299). 


\begin{tabular}{llccc}
\hline Provenance & Terrace & Handaxes & Levallois & $\begin{array}{c}\text { Total } \\
\text { artefacts }\end{array}$ \\
\hline \hline Park's Pit & Lower Warsash & 10 & - & 10 \\
New Pit & Lower Warsash & 15 & 4 & 19 \\
Fleet End Pits & Lower Warsash & 20 & 13 & 35 \\
Button's Pit & Lower Warsash & - & - & 1 \\
Newbury's Pit & Lower Warsash & 6 & - & 7 \\
Dyke's Pit & Lower Warsash & 2 & - & 2 \\
Warsash Church Pit & Lower Warsash & 1 & - & 1 \\
Warsash (General) & Lower Warsash & 200 & 13 & 256 \\
Hook-Chilling Pit & Hamble & 22 & - & 26 \\
Chilling Church Pit & Hamble & 29 & - & 32 \\
Warsash (General) & Unknown & 194 & 4 & 232 \\
\hline Total & & 499 & 34 & 621 \\
\hline
\end{tabular}

Table 3: Provenance of the Warsash Palaeolithic record.

\begin{tabular}{lrrr}
\hline & $\begin{array}{c}\text { Lower } \\
\text { Warsash } \\
\text { Terrace }\end{array}$ & $\begin{array}{c}\text { Hamble } \\
\text { Terrace }\end{array}$ & $\begin{array}{c}\text { Warsash } \\
\text { (General) }\end{array}$ \\
\hline \hline Type D (Crude) & $9.3 \%$ & $6.3 \%$ & $5.9 \%$ \\
Type E (Small) & $6.1 \%$ & - & $4.2 \%$ \\
Type F (Pointed) & $36.6 \%$ & $37.5 \%$ & $38.7 \%$ \\
Type G (Sub-cordate) & $17.5 \%$ & $18.8 \%$ & $17.6 \%$ \\
Type H (Cleaver) & $5.3 \%$ & $6.3 \%$ & $3.4 \%$ \\
Type J (Cordate) & $8.9 \%$ & $12.5 \%$ & $13.4 \%$ \\
Type K (Ovate) & $11.0 \%$ & - & $10.1 \%$ \\
Type M (Ficron) & $2.8 \%$ & - & $1.7 \%$ \\
Type N (Bout Coupé) & - & $6.3 \%$ & - \\
Uniface & $0.8 \%$ & - & $0.8 \%$ \\
Unidentifiable & $1.6 \%$ & $12.5 \%$ & $4.2 \%$ \\
\hline$n$ & 246 & 16 & 119 \\
\hline
\end{tabular}

Table 4: The typological composition of the Warsash handaxes. Based on Wymer's (1968) typology. 


\begin{tabular}{lrrrr}
\hline & Fresh & $\begin{array}{l}\text { Slightly } \\
\text { Rolled }\end{array}$ & Rolled & $\begin{array}{c}\text { Very } \\
\text { Rolled }\end{array}$ \\
\hline \hline Type D (Crude) & - & $7.7 \%$ & $2.9 \%$ & $12.7 \%$ \\
Type E (Small) & - & - & $4.4 \%$ & $8.0 \%$ \\
Type F (Pointed) & $50.0 \%$ & $57.7 \%$ & $50.0 \%$ & $26.7 \%$ \\
Type G (Sub-cordate) & - & $11.5 \%$ & $16.2 \%$ & $19.3 \%$ \\
Type H (Cleaver) & - & $3.8 \%$ & $10.3 \%$ & $3.3 \%$ \\
Type J (Cordate) & - & $3.8 \%$ & $5.9 \%$ & $11.3 \%$ \\
Type K (Ovate) & $50.0 \%$ & $7.7 \%$ & $2.9 \%$ & $14.7 \%$ \\
Type M (Ficron) & - & $3.8 \%$ & $5.9 \%$ & $1.3 \%$ \\
Uniface & - & $3.8 \%$ & $1.5 \%$ & - \\
Unidentifiable & - & - & - & $2.7 \%$ \\
\hline$n$ & 2 & 26 & 68 & 150 \\
\hline
\end{tabular}

Table 5: The typological composition of the Lower Warsash Terrace handaxes from Warsash. Based on Wymer's (1968) typology. 


\begin{tabular}{|c|c|c|c|c|c|}
\hline & Fresh & $\begin{array}{l}\text { Slightly } \\
\text { Rolled } \\
\end{array}$ & Rolled & $\begin{array}{c}\text { Very } \\
\text { Rolled } \\
\end{array}$ & Total \\
\hline Length (mm) & $\begin{array}{r}151.1 \\
\pm 22.8\end{array}$ & $\begin{array}{r}149.4 \\
\pm 45.2\end{array}$ & $\begin{array}{r}143.2 \\
\pm 38.6\end{array}$ & $\begin{array}{r}123.6 \\
\pm 33.1\end{array}$ & $\begin{array}{r}132.2 \\
\pm 37.5\end{array}$ \\
\hline Width (mm) & $\begin{array}{r}79.7 \\
+16.8\end{array}$ & $\begin{array}{r}80.1 \\
+16.8\end{array}$ & $\begin{array}{r}83.3 \\
+19.0\end{array}$ & $\begin{array}{r}76.4 \\
\pm 16.6\end{array}$ & $\begin{array}{r}78.8 \\
+17.5\end{array}$ \\
\hline Thickness (mm) & $\begin{array}{r}35.4 \\
\pm 9.7\end{array}$ & $\begin{array}{r}39.5 \\
\pm 9.0\end{array}$ & $\begin{array}{r}40.5 \\
\pm 9.8\end{array}$ & $\begin{array}{r}37.4 \\
\pm 9.5\end{array}$ & $\begin{array}{r}38.5 \\
\pm 9.6\end{array}$ \\
\hline Elongation & $\begin{array}{r}0.525 \\
\pm 0.032\end{array}$ & $\begin{array}{r}0.556 \\
\pm 0.099\end{array}$ & $\begin{array}{r}0.577 \\
\pm 0.086\end{array}$ & $\begin{array}{r}0.625 \\
\pm 0.100\end{array}$ & $\begin{array}{r}0.603 \\
\pm 0.099\end{array}$ \\
\hline Refinement & $\begin{array}{r}0.441 \\
\pm 0.029\end{array}$ & $\begin{array}{r}0.500 \\
\pm 0.104\end{array}$ & $\begin{array}{r}0.489 \\
\pm 0.077\end{array}$ & $\begin{array}{r}0.497 \\
\pm 0.115\end{array}$ & $\begin{array}{r}0.494 \\
\pm 0.104\end{array}$ \\
\hline Edge Shape & $\begin{array}{r}0.677 \\
\pm 0.381\end{array}$ & $\begin{array}{r}0.610 \\
\pm 0.256\end{array}$ & $\begin{array}{r}0.663 \\
\pm 0.256\end{array}$ & $\begin{array}{r}0.690 \\
\pm 0.188\end{array}$ & $\begin{array}{r}0.673 \\
\pm 0.219\end{array}$ \\
\hline Profile Shape & $\begin{array}{r}0.505 \\
\pm 0.372\end{array}$ & $\begin{array}{r}0.463 \\
\pm 0.143\end{array}$ & $\begin{array}{r}0.493 \\
\pm 0.177\end{array}$ & $\begin{array}{r}0.638 \\
\pm 0.182\end{array}$ & $\begin{array}{r}0.575 \\
\pm 0.192\end{array}$ \\
\hline \multicolumn{6}{|l|}{ Raw Material } \\
\hline Chert & - & $11.5 \%$ & $2.9 \%$ & $4.7 \%$ & $4.9 \%$ \\
\hline Flint & $100.0 \%$ & $88.5 \%$ & $97.1 \%$ & $95.3 \%$ & $95.1 \%$ \\
\hline$n$ & 2 & 26 & 68 & 150 & 246 \\
\hline \multicolumn{6}{|l|}{ Blank Type } \\
\hline Cobble & - & $73.7 \%$ & $75.6 \%$ & $85.7 \%$ & $80.9 \%$ \\
\hline Flake & - & $26.3 \%$ & $24.4 \%$ & $14.3 \%$ & $19.1 \%$ \\
\hline$n$ & 0 & 19 & 49 & 84 & 152 \\
\hline Total Cortex & $\begin{array}{l}6.3 \% \\
\pm 1.8\end{array}$ & $\begin{array}{r}9.8 \% \pm \\
12.4\end{array}$ & $\begin{array}{r}13.3 \% \pm \\
13.2\end{array}$ & $\begin{array}{r}10.5 \% \pm \\
13.9\end{array}$ & $\begin{array}{r}11.2 \% \pm \\
13.5\end{array}$ \\
\hline Scar Index & $\begin{array}{r}0.420 \\
\pm 0.120\end{array}$ & $\begin{array}{r}0.391 \pm \\
0.119\end{array}$ & $\begin{array}{r}0.348 \pm \\
0.101\end{array}$ & $\begin{array}{r}0.357 \pm \\
0.121\end{array}$ & $\begin{array}{r}0.359 \pm \\
0.115\end{array}$ \\
\hline Total Edge & $\begin{array}{r}95.0 \% \\
\pm 7.0 \\
\end{array}$ & $\begin{array}{r}83.2 \% \\
\pm \quad 16.5 \\
\end{array}$ & $\begin{array}{l}77.9 \% \\
\pm 17.1 \\
\end{array}$ & $\begin{array}{l}83.7 \% \\
\pm 17.2 \\
\end{array}$ & $\begin{array}{l}82.1 \% \\
\pm 17.2 \\
\end{array}$ \\
\hline$n$ & 2 & 26 & 68 & 150 & 246 \\
\hline \multicolumn{6}{|l|}{ Butt Working } \\
\hline None & - & $3.8 \%$ & $10.4 \%$ & $3.0 \%$ & $5.2 \%$ \\
\hline Partial & $50.0 \%$ & $76.9 \%$ & $73.1 \%$ & $60.7 \%$ & $66.1 \%$ \\
\hline Full & $50.0 \%$ & $19.2 \%$ & $16.4 \%$ & $36.3 \%$ & $28.7 \%$ \\
\hline$n$ & 2 & 26 & 67 & 135 & 230 \\
\hline
\end{tabular}

Table 6: Mean and standard deviation, and frequency of a selection of attributes of the Lower Warsash handaxes. Elongation = width/length; Refinement = thickness $/$ width; Edge shape = tip width/butt width; Profile shape = tip thickness/butt thickness. 


\begin{tabular}{|c|c|c|c|c|c|c|}
\hline & \multicolumn{2}{|c|}{ Levallois flakes } & \multicolumn{2}{|c|}{ Levallois cores } & \multicolumn{2}{|c|}{$\begin{array}{c}\text { Simple Prepared } \\
\text { Cores }\end{array}$} \\
\hline & Fresh & Rolled & Fresh & Rolled & Fresh & Rolled \\
\hline \multicolumn{7}{|l|}{ Bournemouth } \\
\hline Knighton Lodge Terrace (Terrace 8) & 3 & 2 & - & - & . & 2 \\
\hline $\begin{array}{l}\text { West Southbourne Terrace (Terrace } \\
\text { 9) }\end{array}$ & 1 & - & - & - & . & 2 \\
\hline Ensbury Park Terrace (Terrace 10) & 3 & 7 & 1 & 3 & 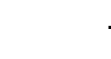 & - \\
\hline Gravel Hill Terrace (Terrace 11) & 1 & - & - & - & . & - \\
\hline \multicolumn{7}{|l|}{ Test } \\
\hline Hamble Terrace & - & 1 & 1 & - & . & - \\
\hline Mottisfont-Lower Warsash Terrace & 16 & 1 & 5 & 2 & . & - \\
\hline Belbin-Upper Warsash Terrace & 4 & 3 & - & - & . & 3 \\
\hline
\end{tabular}

Table 7: The distribution and condition of Solent Levallois artefacts located and recorded by Davis (2013). Fresh and slightly rolled artefacts are grouped in the fresh category, rolled and very rolled in the rolled category. Bournemouth terrace nomenclature after Westaway et al. (2006). 


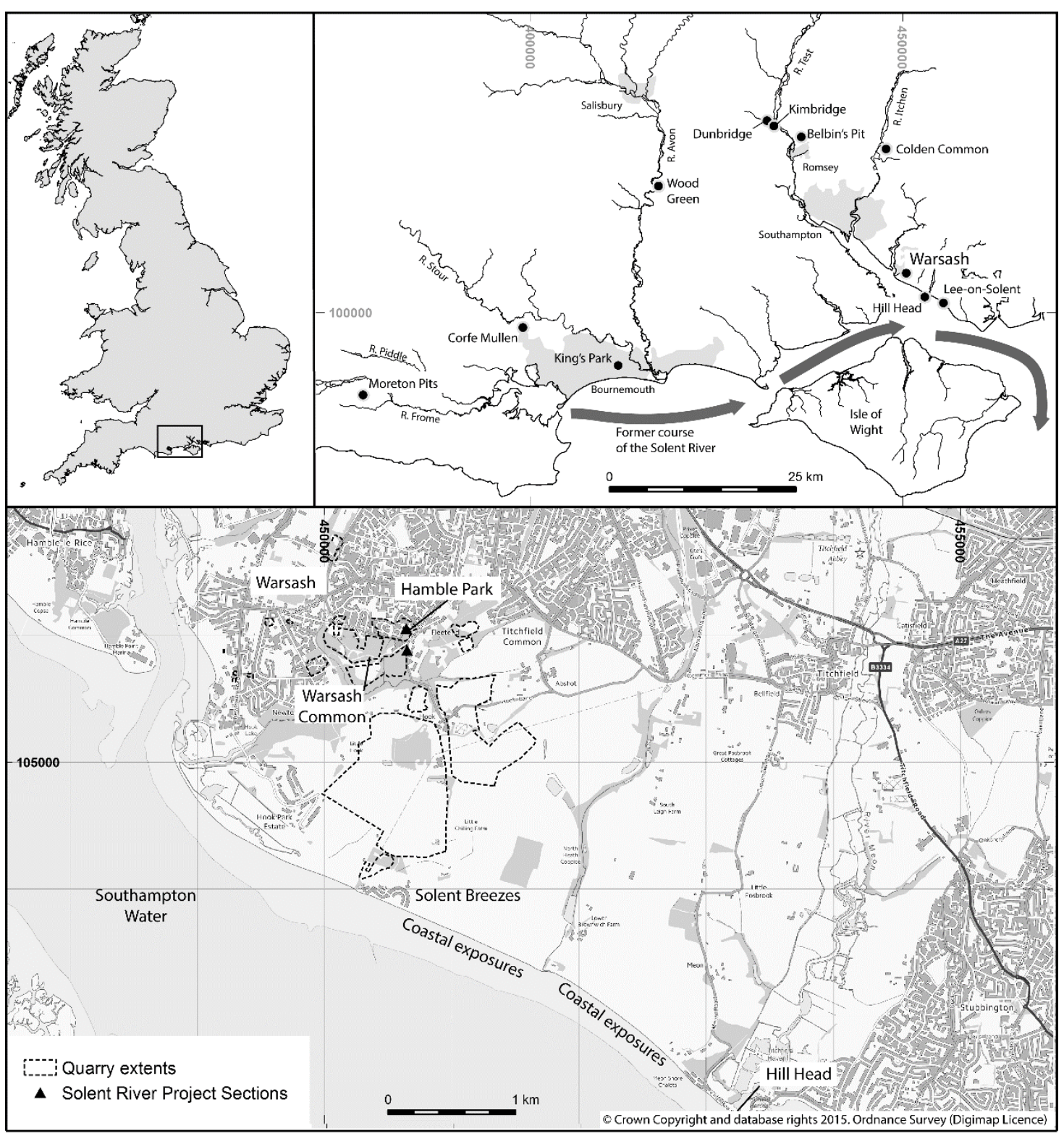

Fig. 1: Location of Warsash, with former quarry extents and recent fieldwork sites shown. Inset: the wider Solent region, with other important archaeological sites located. 


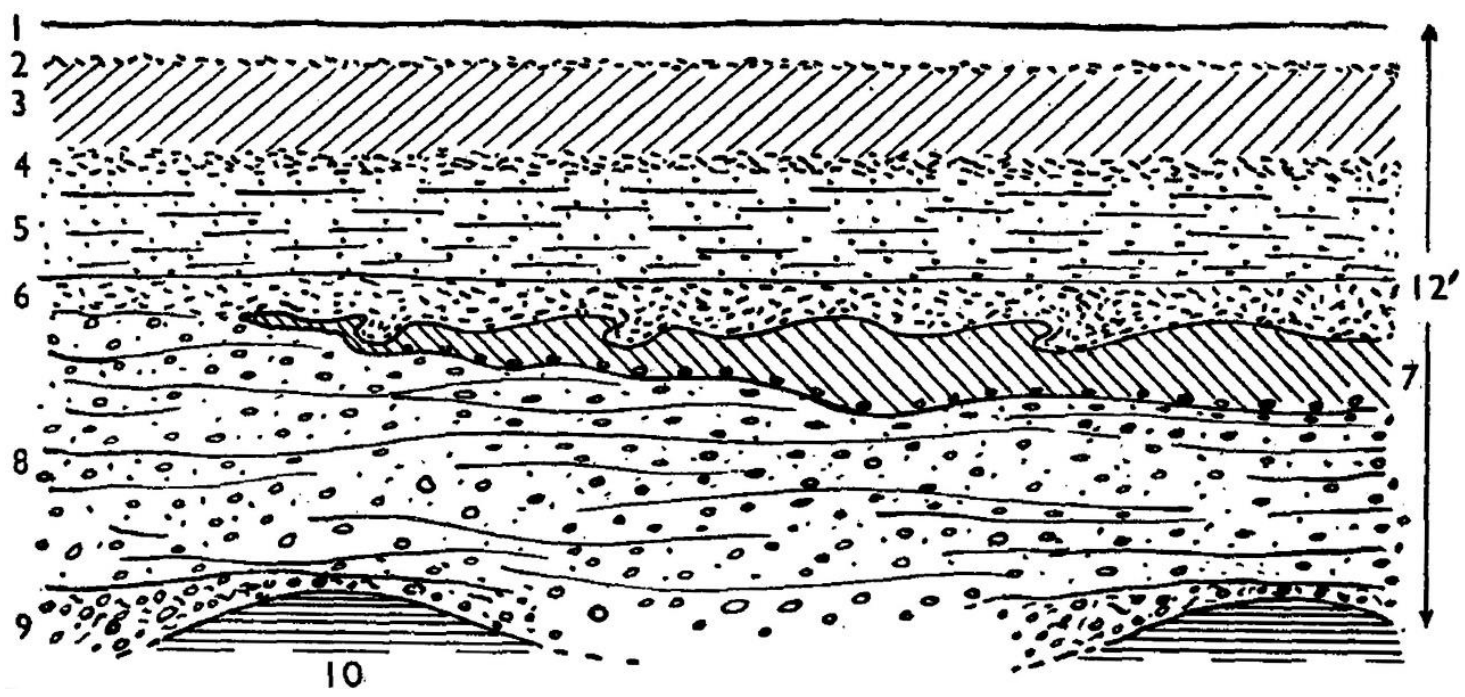

Fig. 2: Composite section from Newbury's Pit, Warsash (Burkitt et al. 1939: Fig. 2). (1) Black pebbly sand; (2) thin basal layer of angular gravel; (3) buff stony loam; (4) fine angular gravel; (5) fine, even bedded, gravelly sand with occasional sand lenses; (6) fine gravel; (7) nonferruginous, grey, clayey sand; (8) coarse, loose, ferruginous gravel; (9) coarse brown gravel conglomerate; (10) Barton Sand. 


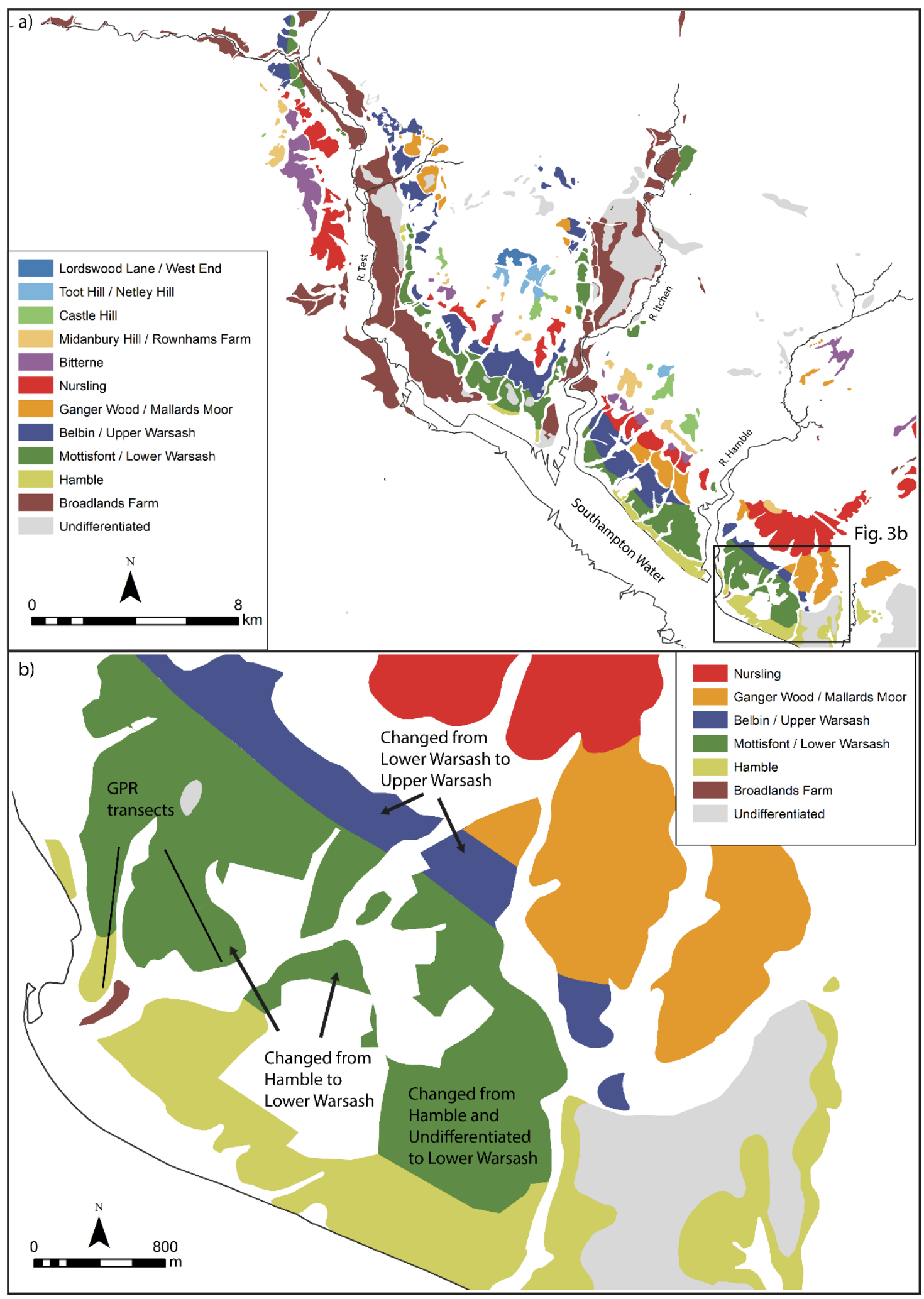

Fig. 3: The fluvial terraces of the rivers Test and Itchen (a) and in the Warsash area (b). The changes made to the local terrace mapping by Hatch (2014; Hatch et al. in revision.) are indicated, as are Hatch's two key GPR transects. 


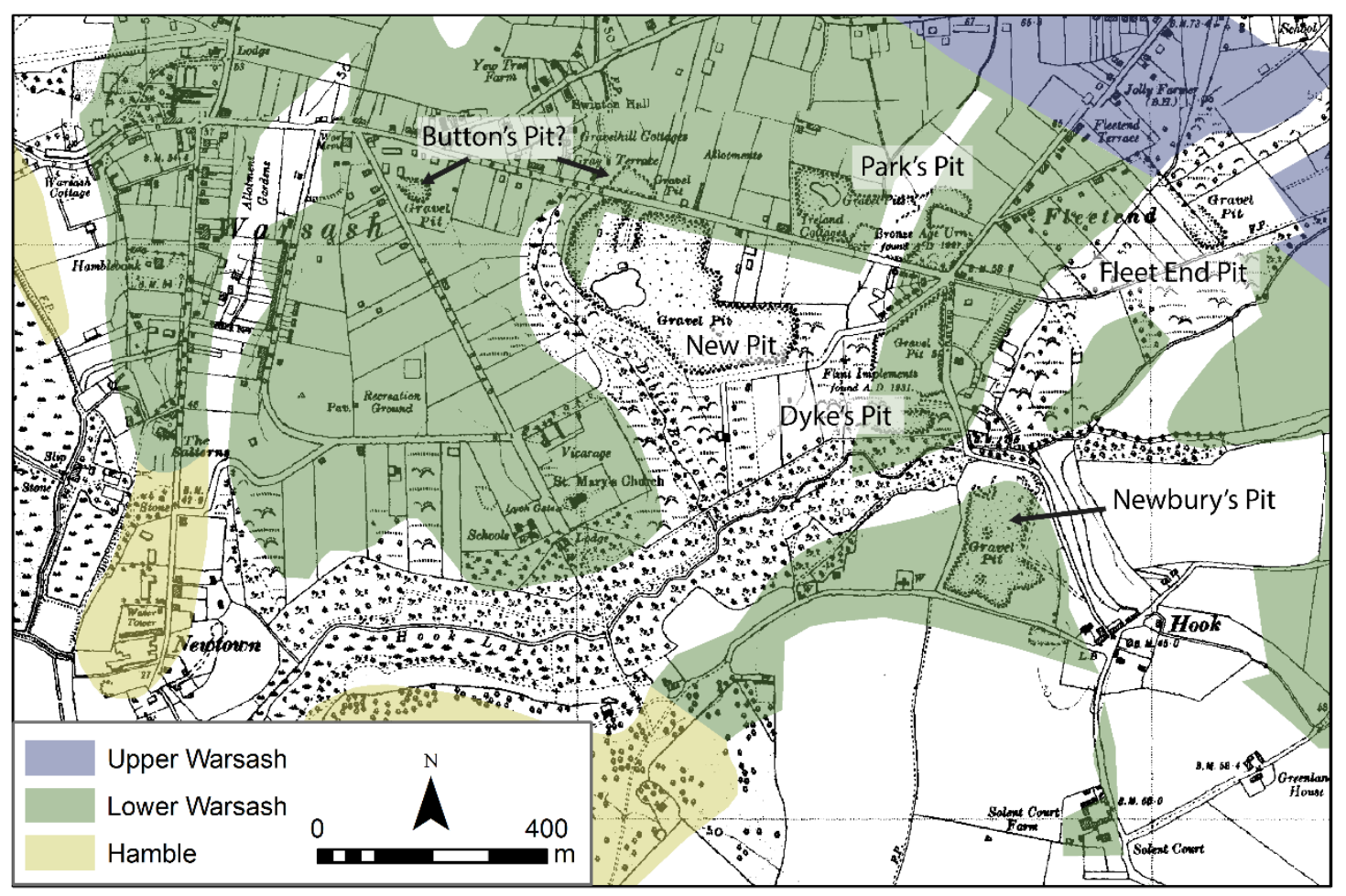

Fig. 4: The Warsash gravel pits in 1942. This is the area between Warsash and Hook described by Burkitt et al. (1939). Note the annotations recording the discovery of Palaeolithic artefacts and prehistoric pottery. Pit locations after Parkes (1947). Created using $3^{\text {rd }}$ Rev. (1942) 1:10,560 County Series (Hampshire Sheet), (c) Crown Copyright and Landmark Information Group Limited (2016). All rights reserved (1942).

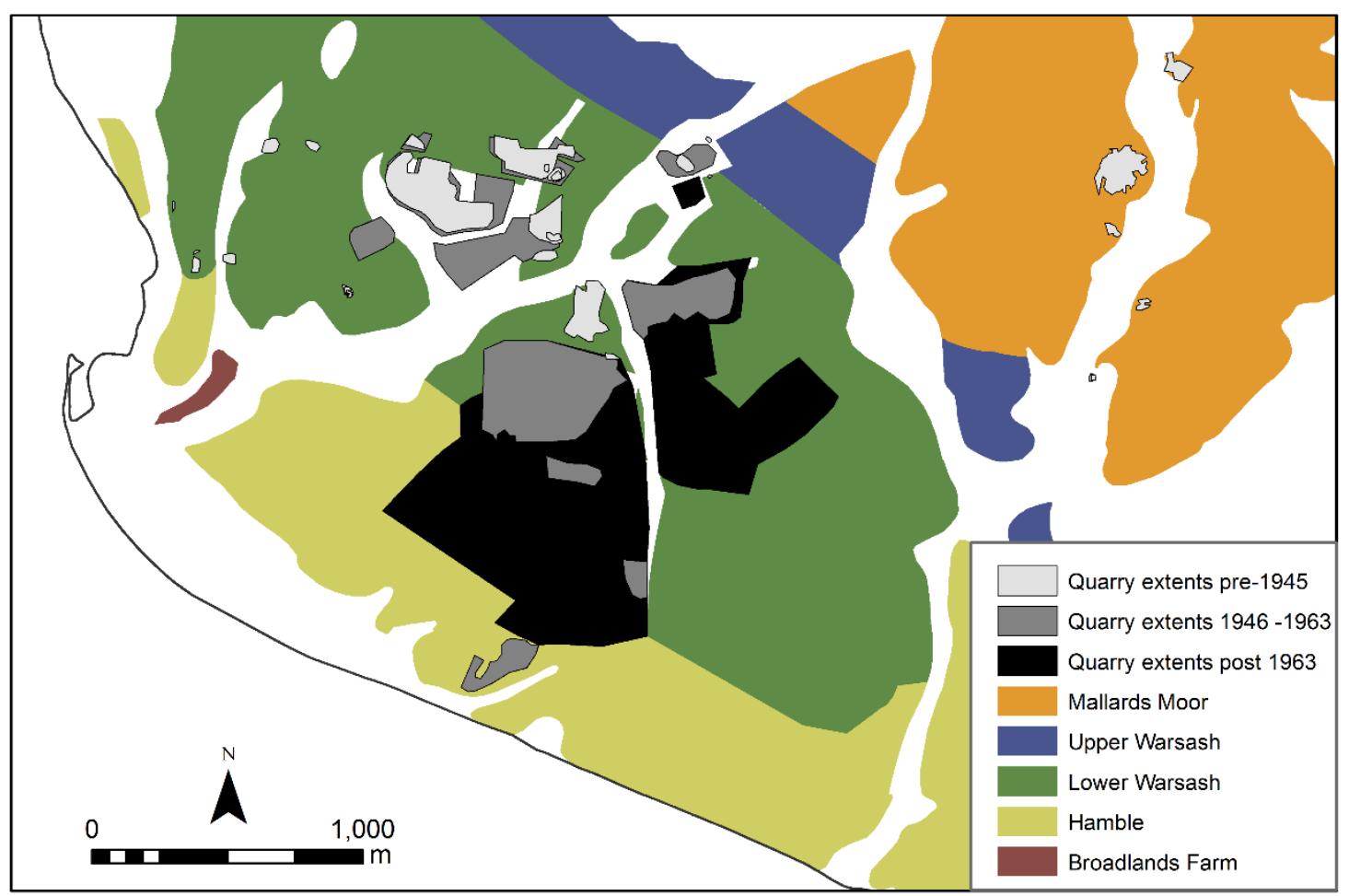

Fig. 5: Map showing the development of the Warsash gravel pits through time. 


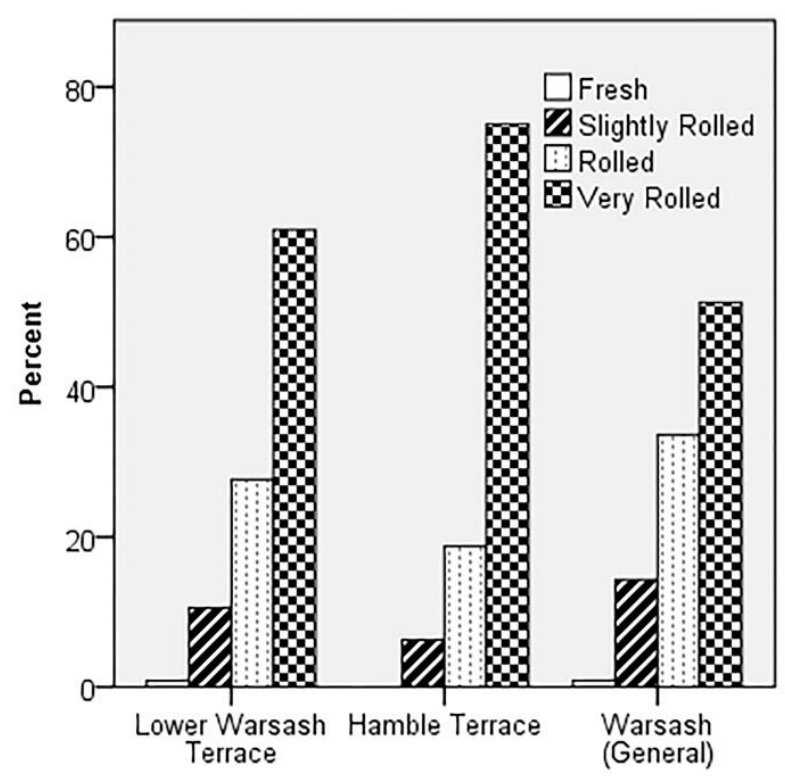

Fig. 6: The degree of rolling of the Warsash handaxes.
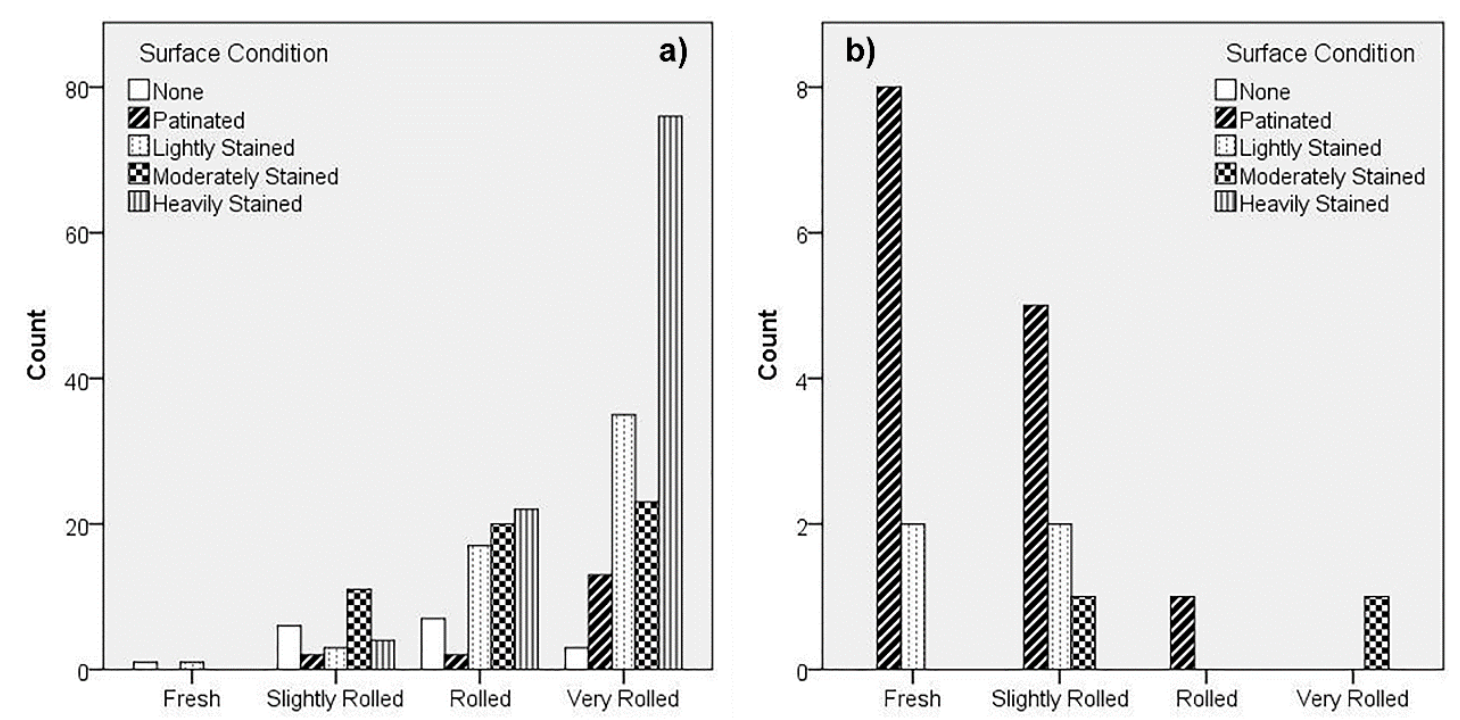

Fig. 7: The degree of rolling and surface condition of (a) the Lower Warsash handaxes and (b) the Levallois artefacts (b). 


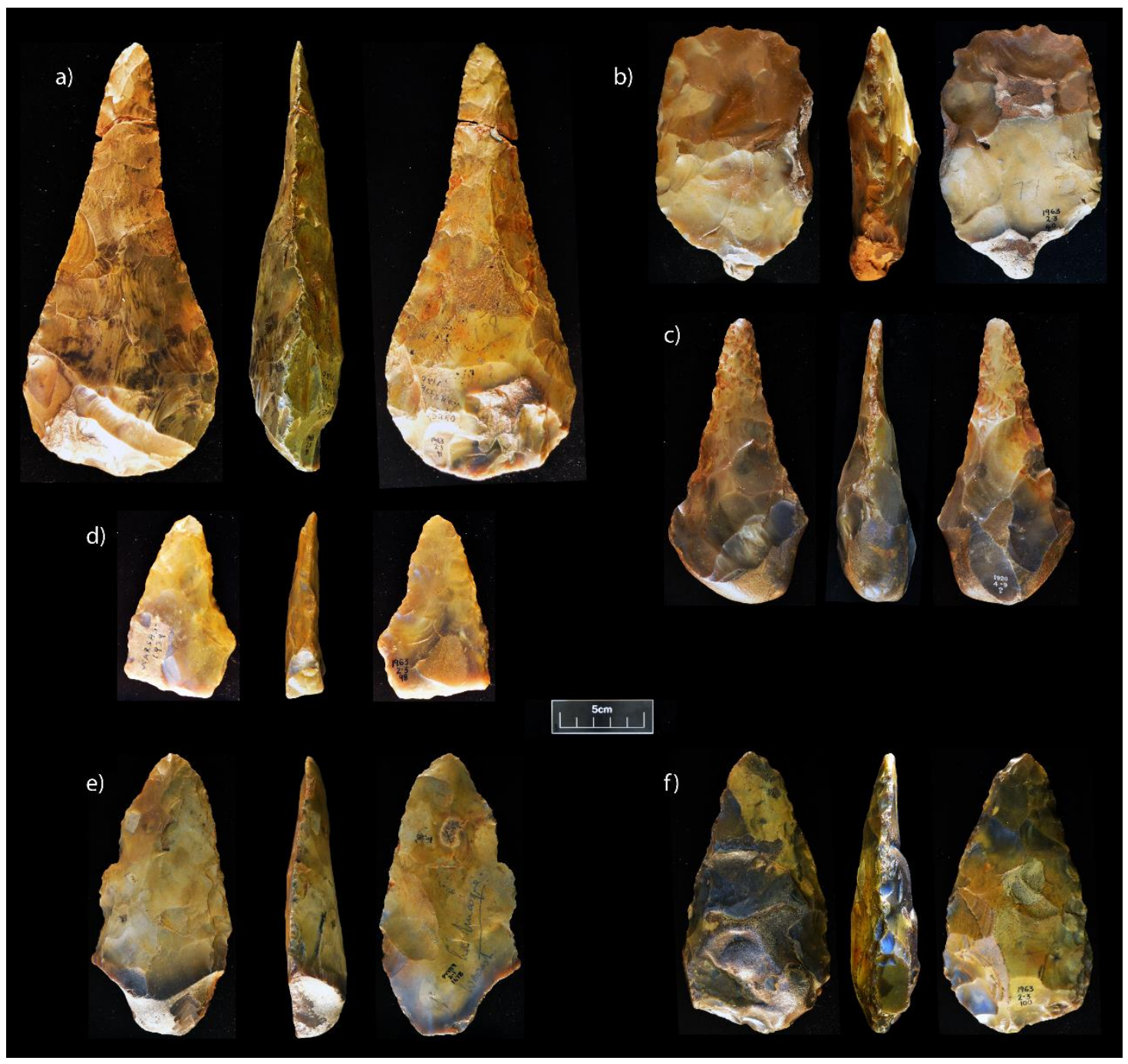

Fig 8: Examples of Warsash handaxes. a) and c) ficrons; b) cleaver; d) plano-convex handaxes made on flat cobble; e) plano-convex handaxe made on a flake; f) pointed handaxe. Reproduced courtesy of the British Museum. 


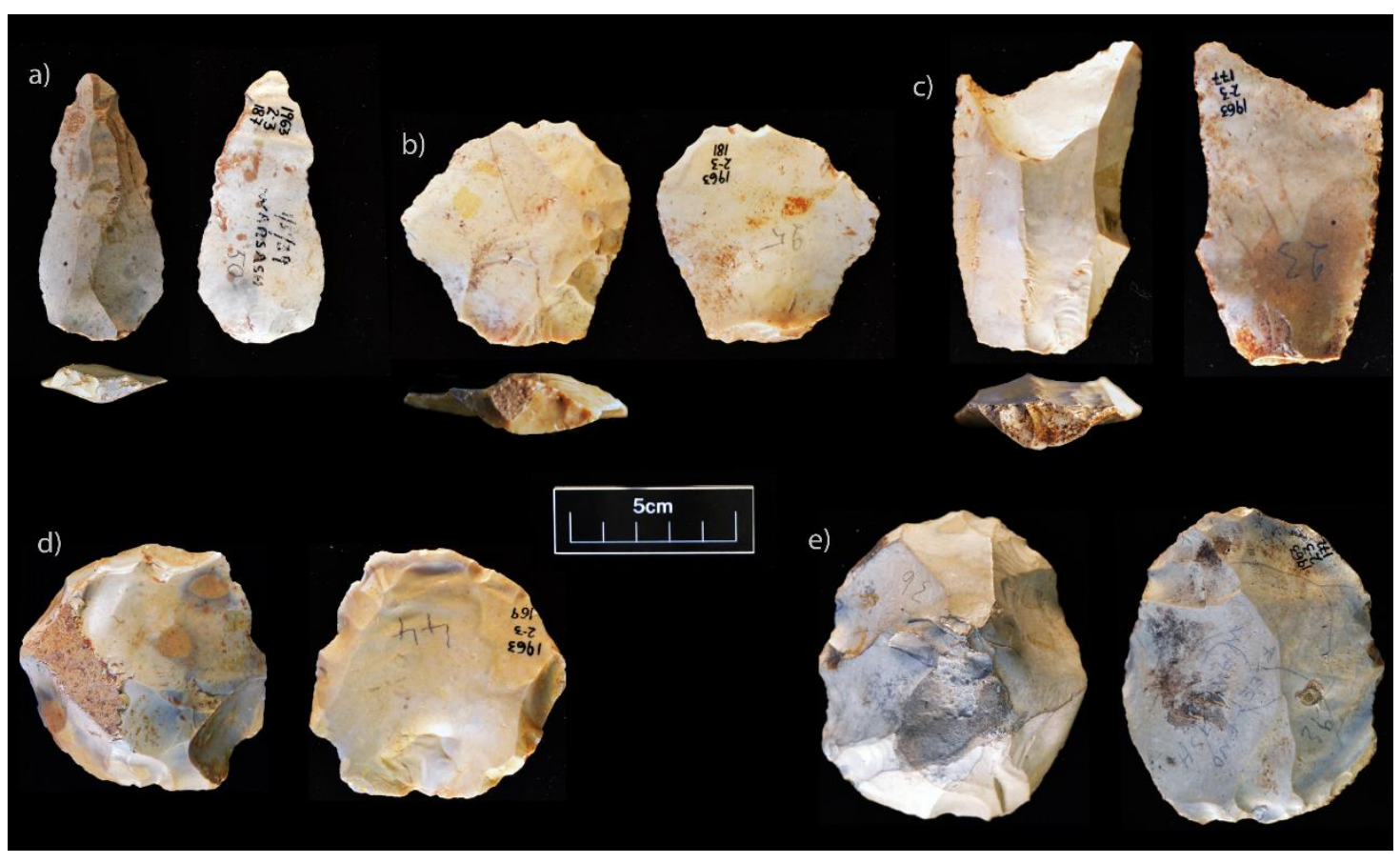

Fig 9: Levallois artefacts from Warsash. a), b) and c) Levallois flakes; d) and e) Levallois cores. Reproduced courtesy of the British Museum. 